7-1-2021

\title{
Separation, Supremacy, and the Unconstitutional Rational Basis Test
}

Joseph S. Diedrich

Follow this and additional works at: https://digitalcommons.law.villanova.edu/vlr

Part of the Constitutional Law Commons

\section{Recommended Citation}

Joseph S. Diedrich, Separation, Supremacy, and the Unconstitutional Rational Basis Test, 66 Vill. L. Rev. 249 (2021).

Available at: https://digitalcommons.law.villanova.edu/vlr/vol66/iss2/1

This Article is brought to you for free and open access by Villanova University Charles Widger School of Law Digital Repository. It has been accepted for inclusion in Villanova Law Review by an authorized editor of Villanova University Charles Widger School of Law Digital Repository. 


\title{
VILLANOVA LAW REVIEW
}

Volume 66

2021

Number 2

\author{
Articles \\ SEPARATION, SUPREMACY, AND THE \\ UNCONSTITUTIONAL RATIONAL BASIS TEST
}

Joseph S. Diedrich*

Abstract

When using a judicial tool known as the rational basis test, courts uphold a federal or state statute as constitutional so long as the statute rationally relates to a legitimate government interest. In this Article, I contribute a new theory to a growing body of scholarship questioning the validity of the rational basis test. I argue that the test violates the structural separation of powers and the Supremacy Clause of the U.S. Constitution.

Article III of the Constitution vests federal courts with the "judicial power." This power entails applying law to decide particular disputes; interpreting the law in order to apply it; and, when faced with multiple conflicting sources of law, applying higher-order law and rendering lowerorder law void or unenforceable. On that last point, the Supremacy Clause provides that the Constitution prevails over contrary federal and state statutes.

I argue that when they deploy the rational basis test in cases challenging statutes, courts abdicate part of their judicial power and duty. Instead of fully exercising the judicial power to ascertain the best, fairest, and correct interpretation of the constitutional provision at issue, they merely set a zone of deference, within which all rational interpretations reside. The abdicated judicial power is effectively transferred to Congress or the state legislature (as the case may be), which then exercises the remnant judicial power-much like how Chevron deference results in transfer of judicial power to the executive branch. When used to review a federal statute, this framework violates the separation of powers. And when used to review any statute, it subverts the Supremacy Clause's established legal hierarchy by elevating the status of lower-order statutes and illegitimately demoting the Constitution.

* Appellate Attorney, Husch Blackwell LLP, Madison, Wisconsin. J.D., University of Wisconsin, summa cum laude, Order of the Coif. Special thanks to Philip Hamburger, Jeffrey Jackson, Kirsten Atanasoff, Kevin LeRoy, Clark Neily, Alex Phillips, and Yue Zhang for their comments, critiques, and support. All opinions are mine alone. 


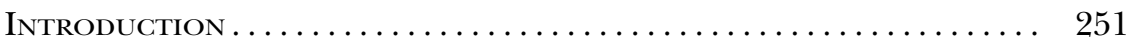

I. The Rational Basis Test ....................... 255

II. Constitutional Principles............................. 261

A. Separation of Powers .............................. 261

B. "Judicial Power" ................................. 264

C. Supremacy Clause............................ 271

III. Chevron Deference: The Analogy .................. 273

A. Challenging Administrative Rules ................. 274

B. Chevron and the Zone of Deference ................. 276

C. Constitutional Problems with Chevron Deference .......... 279

IV. Why the Rational Basis Test Is Unconstitutional ...... 286

A. Judicial Review of Statutes ........................ 286

B. Rational Basis and the Zone of Deference.............. 288

C. Constitutional Problems with Rational Basis Review of Federal Statutes ................................ 290

D. Constitutional Problems with Rational Basis Review of State

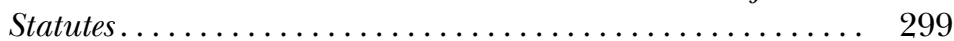

V. Counterarguments ............................ 301

Conclusion......................................... 308 


\section{INTRODUCTION}

$\mathrm{T}$ HE Constitution is law, and "[i]t is emphatically the province and duty of the judicial department to say what the law is." " Not what the law rationally might be. And not what Congress or any state legislature says it is.

As part of the New Deal-era reaction against Lochner $v$. New York ${ }^{2}$ and its ilk, the United States Supreme Court developed a now-familiar framework to review the constitutionality of many types of government action: the "rational basis test." Under that test, if a federal or state statute rationally relates to a legitimate government interest, then a federal court (or a state court applying federal law) blesses it as consistent with the United States Constitution and applies it to resolve the case at hand.

In this Article, I argue that the modern rational basis test-irrespective of the outcomes it produces-is unconstitutional. I am hardly the first person to say so. The Georgetown Journal of Law and Public Policy devoted an entire symposium to the proposition. ${ }^{3}$ Randy Barnett has argued that "a two-tier treatment of constitutional rights violates both the plain and original meaning of the Ninth Amendment," 4 which states that unenumerated rights should not be "den[ied] or disparage[d]." ${ }^{5}$ Clark Neily has argued

1. Marbury v. Madison, 5 U.S. (1 Cranch) 137, 177 (1803).

2. 198 U.S. 45 (1905).

3. See generally Evan Bernick, Subjecting the Rational Basis Test to Constitutional Scrutiny, 14 Geo. J.L. \& Pub. Pol'y 347 (2016).

4. Randy E. Barnett, Scrutiny Land, 106 Mich. L. Rev. 1479, 1496 (2008); see also Randy Barnett, Judicial Engagement Through the Lens of Lee Optical, 19 Geo. Mason L. Rev. 845, 858 (2012) [hereinafter Barnett, Judicial Engagement]; Randy E. Barnett, Does the Constitution Protect Economic Liberty?, 35 Harv. J.L. \& Pub. Pol'y 5, 12 (2012); Jeffrey D. Jackson, Putting Rationality Back into the Rational Basis Test: Saving Substantive Due Process and Redeeming the Promise of the Ninth Amendment, $45 \mathrm{U}$. Rich. L. Rev. 491, 548 (2011); Clark Neily, No Such Thing: Litigating Under the Rational Basis Test, 1 N.Y.U. J.L. \& LiberTy 898, 914 (2005) [hereinafter Neily, No Such Thing] ("The Ninth Amendment says that unenumerated rights should neither be denied nor disparaged. But it is hard to imagine how one could more thoroughly 'disparage' a constitutional right than to appoint as its sole guardian the rational basis test. The Supreme Court should have the courage either to expressly disavow economic liberties-and accept whatever consequences might flow from explicitly rejecting centuries of common law, overturning over one hundred years of precedent, and repudiating a core value of the founding fathers-or else devise a test for protecting those rights that contains some measure of integrity.”).

5. U.S. Const. amend. IX. 
that the rational basis test raises due process ${ }^{6}$ and equal protection ${ }^{7}$ concerns. Jeffrey Jackson has argued that the test violates the Constitution by permitting arbitrary legislation. ${ }^{8}$ Still others have assailed the rational basis test on other constitutional and policy grounds. ${ }^{9}$

This Article contributes a new theory of the rational basis test's constitutional shortcomings: I argue that the test violates the separation of powers and the Supremacy Clause. Particularly given several Justices' renewed interest in enforcing the separation of powers and related doctrines, ${ }^{10}$ this Article's theory may prove especially timely and relevant.

To understand the basic contours of my claim, consider first the separation of powers. Building on intellectual foundations laid by liberal political philosophy, and reacting to negative experiences with accumulated power, the Constitution creates three separate branches of the federal gov-

6. See Neily, No Such Thing, supra note 4, at 907-08 ("It is a bedrock principle of common law that parties to court proceedings are entitled to a neutral adjudicator who is free from bias and even the appearance of bias. Indeed, so fundamental is that principal that the Supreme Court considers it an indispensable requirement of due process. But like so many of our most cherished legal traditions, that one goes right out the window in rational basis cases, where judges are not only permitted but required to assist the government in defending challenged regulations by dreaming up possible justifications of their own." (footnotes omitted)); see also Clint Bolick, The Proper Role of "Judicial Activism," 42 Harv. J.L. \& Pub. Pol'y 1, 5-6 (2019) (" $[\mathrm{A}] \mathrm{n}$ individual who possesses a right under the Constitution walks into the courtroom, and the government walks into the courtroom, and the scales of justice tilt in favor of the government. Instead of simply interpreting the individual's right against the government power on equal terms, a presumption of the statute's constitutionality forces the individual to prove what is, in some instances, a metaphysical impossibility." (footnote omitted)); Randy E. Barnett, Why Popular Sovereignty Requires the Due Process of Law to Challenge "Irrational or Arbitrary" Statutes, 14 Geo. J.L. \& Pub. Pol'y 355 (2016).

7. Clark Neily, Litigation Without Adjudication: Why the Modern Rational Basis Test Is Unconstitutional, 14 GEo. J.L. \& Pub. POL'y 537, 551 (2016) [hereinafter Neily, Litigation] ("[T] he rational basis test is applied inconsistently, with some litigants receiving the meaningful, truth-seeking version of the test reflected in such well-known 'rational basis with bite' cases as Cleburne, Moreno, and Romer, while others receive the rubber-stamp version that virtually assures the law will be upheld regardless of its true ends or the means used to advance them.").

8. Jeffrey D. Jackson, Classical Rational Basis and the Right to Be Free of Arbitrary Legislation, 14 Geo. J.L. \& Pub. Pol'y 493, 509 (2016) [hereinafter Jackson, Classi$\mathrm{cal}$ (" $[\mathrm{T}]$ he modern rational basis test fits this bill for one simple reason; it allows arbitrary legislation. It gives legislation not actually reasonably related to a legitimate governmental purpose the status of positive law. This is contrary to one of the most fundamental tenants of American constitutionalism, which is that laws must not be unreasonable.").

9. See, e.g., Aaron Belzer, Putting the "Review" Back in Rational Basis Review, 41 W. Sт. U. L. Rev. 339, 389 (2014); Richard A. Epstein, Rational Basis Review and FDA Regulation: Why the Two Do Not Mix, 14 Geo. J.L. \& Pub. Pol'y 417 (2016); Joseph Landau, Broken Records: Reconceptualizing Rational Basis Review to Address "Alternative Facts" in the Legislative Process, 73 VAND. L. REv. 425 (2020); Michael Stokes Paulsen, Medium Rare Scrutiny, 15 Const. Comment. 397 (1998).

10. See infra notes 131 (non-delegation doctrine), 160; see also, e.g., Seila Law v. Consumer Fin. Prot. Bureau, 140 S. Ct. 2183 (2020) (holding that federal agency's structure violated the separation of powers). 
ernment and vests each branch with a distinct power. This tripartite division is both simple and profound: Congress exercises will; the President and executive branch exercise force; and courts exercise judgment. Because separation fosters individual liberty, the Constitution prohibits any branch from encroaching onto another's power or from abdicating its own power and transferring it elsewhere.

Second, consider the judicial power. The Constitution vests the federal courts with the "judicial power." 11 Although undefined, this phrase's meaning derives from a rich history and a voluminous jurisprudential exegesis. It contains three critical components. The first is the power to apply law (general rules of conduct) to adjudicate particular disputes. The second is the power, in the course of adjudicating disputes, to interpret the law and to ascertain its best, fairest, and correct meaning. ${ }^{12}$ The third is the power and duty to decide in accord with higher-order law when multiple sources of law conflict. Together with the separation of powers, the judicial power and duty authorize what is commonly known as judicial review-of all government action, including federal and state legislative enactments.

Third and finally, consider the Supremacy Clause. Article VI of the Constitution establishes a legal hierarchy by designating certain sources of law-the Constitution and federal statutes "made in Pursuance" of itsupreme. ${ }^{13}$ To that end, the Supremacy Clause provides that federal law prevails over contrary state law. And it provides that the Constitution prevails over federal statutes not "made in Pursuance" of it. All this together means that the Supremacy Clause informs judges how to discharge their judicial duty: when a state or federal statute is contrary to the Constitution, the latter prevails to the exclusion of the former.

The rational basis test disturbs all three constitutional principles. When a party challenges a federal statute as contrary to the Constitution, the judicial power-vested solely in the courts-would entail fully ascertaining the best, fairest, and correct meaning of the lower-order federal statute and of the higher-order constitutional provision. If they are indeed contrary to one another, then the constitutional provision renders the statute unenforceable, at least in that particular case. But that's not what happens under the rational basis test. Instead of exercising the judicial power to fully interpret the best, fairest, and correct meaning of the constitu-

11. U.S. Const. art. III $\S 1$.

12. I use the phrase "best, fairest, and correct meaning"-or some close variant of it-throughout this Article. Case law and secondary sources have used the terms "best," "fairest," "right," or "correct" (or some combination of those terms) roughly interchangeably to describe an interpretation of law that is definite and that results from a court's independent judgment. I use the phrase "best, fairest, and correct meaning" to indicate that basic idea, as clarified or adorned by context. Although I realize the phrase "best, fairest, and correct" might seem (and might even be) redundant or contradictory, I ask you to bear with me: it will make sense based on the existing authorities.

13. U.S. Const. art. VI $\$ 2$. 
tional provision at issue, courts stop short. They ask only whether Congress acted rationally in enacting the statute. In so doing, courts effectively transfer part of the judicial power to Congress, substituting Congress's interpretation of the Constitution in a particular case. This violates the separation of powers. And it also subverts the Supremacy Clause's legal hierarchy, illegitimately raising the status of federal statutes and diminishing the status of the Constitution.

No less troubling, rational basis review of state statutes leads to similar problems. Although the same federal separation-of-powers concerns do not arise, abdication and transfer still occur-this time, the transfer of judicial power is to another sovereign. And it magnifies the Supremacy Clause flaw: although scholars have argued about how that Clause applies to federal statutes, everyone concurs that it clearly limits state power and clearly authorizes judicial review of state action.

If my arguments about the rational basis test sound at least vaguely familiar, there's a reason why: jurists and scholars have been launching similar attacks against Cheuron ${ }^{14}$ deference for years. Courts apply Cheuron deference when a party challenges an administrative rule (adopted by an executive-branch agency) as inconsistent with a statute. If the statute is ambiguous, Chevron instructs courts to refrain from fully ascertaining the best, fairest, and correct meaning of the statute-and to instead ask merely if the administrative rule amounts to a permissible construction. Although there are many arguments critical of Chevron deference, one in particular attacks the doctrine as violating the separation of powers. By deferring to the executive branch's interpretation of law in a particular case, the argument goes, courts abdicate and transfer part of the judicial power. I offer this argument as an analogy. After all, both Chevron deference and the rational basis test are used when a party argues that a lowerorder law (administrative rule or statute, respectively) conflicts with a higher-order law (statute, Constitution, respectively).

In Part I of this Article, I set forth the basic contours of the rational basis test. To provide context, I trace its history back to a precursor in the late 1800 s, through its introduction as a reaction against Lochner-era jurisprudence, and through its maturation in modern Supreme Court case law. I also explain how the rational basis test permeates a wide range of contemporary jurisprudence and is used to evaluate the constitutionality of vast swaths of government action, particularly federal and state statutes.

As explained, my ultimate goal in this Article is to show that the rational basis test is inconsistent with certain constitutional principles and provisions. I devote Part II to discussing those principles and provisions: the separation of powers, the "judicial power" vested in the federal courts under Article III, and the Supremacy Clause. For each, I provide textual, contextual, and historical detail necessary to understanding what the provisions and principles mean and how they inform my ultimate argument.

14. Chevron U.S.A., Inc. v. Nat. Res. Def. Council, Inc., 467 U.S. 837 (1984). 
In Part III, I present the Cheuron-deference analogy. I explain what Chevron deference is and how it is used. I review judicial and scholarly arguments asserting that Chevron deference violates the separation of powers by requiring courts to abdicate judicial power and transfer it to the executive branch. I also add that this framework subverts the Supremacy Clause's established legal hierarchy.

Part IV comprises my main argument. In brief, I argue that when applying the rational basis test, federal courts abdicate judicial power and transfer it either to Congress (when federal statutes are under review) or to state legislatures (when state statutes are under review). The first violates the separation of powers; both violate the Supremacy Clause. This line of argument borrows directly from the well-known constitutional arguments against Cheuron deference.

Further, in Part V, I address several likely counterarguments. Finally, I offer some concluding thoughts.

\section{The Rational Basis Test}

Under the modern constitutional-law superstructure that emerged from the watershed decision in United States v. Carolene Products ${ }^{15}$ and its famous fourth footnote, ${ }^{16}$ courts review government action-including legislation-using a tiered-scrutiny framework. ${ }^{17}$ On the one hand, statutes burdening certain rights or creating certain classifications receive strict or otherwise heightened judicial scrutiny. On the other hand, the default (and least scrutinous) standard of review is rational basis scrutiny ${ }^{18}$ - a test "enormously deferential to the government" that "only rarely" results in "the Supreme Court invalidat[ing] laws." 19 The rational basis test instructs a court to uphold a federal or state statute if it is ration-

15. 304 U.S. 144 (1938).

16. Id. at 152 n.4 ("There may be narrower scope for operation of the presumption of constitutionality when legislation appears on its face to be within a specific prohibition of the Constitution ....."); see Jack M. Balkin, The Footnote, 83 Nw. U. L. REv. 275, 282-93 (1989).

17. See generally Erwin Chemerinsky, The Rational Basis Test Is Constitutional (and Desirable), 14 Geo. J.L. \& Pub. Pol'y 401, 401-02 (2016); Jackson, Classical, supra note 8, at 507-08. Although generally accepted, this "hornbook" model of judicial scrutiny, Suzanna Sherry has argued, "has not fully reflected the actual jurisprudence of the Supreme Court (or lower courts) in decades." Suzanna Sherry, Selective Judicial Activism: Defending Carolene Products, 14 Geo. J.L. \& Pub. Pol'y 559, 561 (2016). "Instead, the Court has essentially adopted a sliding scale, under which the level of governmental justification needed to sustain a challenged law depends on the strength of the presumption of constitutionality." Id.

18. Several commentators have noted that courts inconsistently formulate the rational basis test and, in turn, have argued that the rational basis test is actually a collection of multiple tests. See, e.g., Neily, Litigation, supra note 7, at 539-40; see also Robert C. Farrell, Equal Protection Rational Basis Cases in the Supreme Court Since Romer v. Evans, 14 Geo. J.L. \& Pub. Pol'y 441, 456 (2016) [hereinafter Farrell, Equal Protection]; Sherry, supra note 17, at 560; Paulsen, supra note 9.

19. Chemerinsky, supra note 17, at 401-02; see also Farrell, Equal Protection, supra note 18, at 442 (noting low success rate of challenges subjected to rational 
ally related to any legitimate government interest or purpose. ${ }^{20}$ " $[\mathrm{T}]$ he government's objective only need be a goal that is legitimate for the government to pursue," and that goal "need not be the actual purpose of the legislation, but rather any conceivable legitimate purpose."21

The modern, canonical rational basis test is defined by two cases: Williamson v. Lee Optical ${ }^{22}$ and Federal Communications Commission v. Beach Communications, Inc. ${ }^{23}$ Williamson involved an Oklahoma statute mandating that only licensed optometrists or ophthalmologists-not opticianscould fit, duplicate, or replace eyeglass lenses. The lower court held that the statute was protectionist and "deprive[d] opticians of their right to freely pursue a lawful calling," ${ }^{24}$ but the Supreme Court saw things differently. Without any evidentiary support, the Court surmised that the Oklahoma legislature "might have" concluded the statute was necessary to protect the public health. ${ }^{25}$ Although the Oklahoma statute admittedly could "exact a needless, wasteful requirement in many cases," the Court reasoned that it "need not be in every respect logically consistent with its aims to be constitutional." 26 "It is enough that there is an evil at hand for correction, and that it might be thought"-again, even without evidentiary basis-"that the particular legislative measure was a rational way to correct it." 27

The Beach Court doubled down on Williamson's deference while reviewing a federal statute exempting some, but not all, cable television facilities from regulation. Writing for the majority, Justice Clarence Thomas reiterated Williamson's implication that a statute passes constitutional muster so long as "any reasonably conceivable state of facts . . could provide a rational basis for" it. ${ }^{28}$ Expanding on how to implement the test, the Court explained that "those attacking the rationality" of a law must "negative every conceivable basis which might support it," and that "a legislative choice ... may be based on rational speculation unsupported by evidence

basis review); Farrell, Successful Rational Basis Claims in the Supreme Court from the 1971 Term Through Romer v. Evans, 32 Ind. L. Rev. 357, 370 (1999) (same).

20. Chemerinsky, supra note 17 , at 401 .

21. Id. at 401-02 (first citing Schweiker v. Wilson, 450 U.S. 221, 235 (1981); then citing U.S. R.R. Ret. Bd. v. Fritz, 449 U.S. 166, 174 (1980)).

22. 348 U.S. 483 (1955).

23. 508 U.S. 307 (1993).

24. Lee Optical v. Williamson, 120 F. Supp. 128, 136 (W.D. Okla. 1954), rev'd, 348 U.S. 483 (1955). See generally Barnett, Judicial Engagement, supra note 4.

25. Williamson, 348 U.S. at 487.

26. Id. at $487-88$.

27. Id. at 488 (emphases added).

28. Beach, 508 U.S. at 313; see also U.S. R.R. Ret. Bd. v. Fritz, 449 U.S. 166, 174 (1980) (quoting Lindsley v. Nat. Carbonic Gas Co., 220 U.S. 61, 78-79 (1911)) (" $[\mathrm{W}]$ hen the classification in such a law is called in question, if any state of facts reasonably can be conceived that would sustain it, the existence of that state of facts at the time that the law was enacted must be assumed."). 
or empirical data." ${ }^{29}$ Presaging subsequent scholarly criticism, Justice Stevens opined in concurrence that "judicial review under the "conceivable set of facts' test is tantamount to no review at all." 30

This modern, canonical rational basis test, forged from Carolene Products and crystallized in Williamson and Beach, is the subject of this Article. Yet both for context and to fulfill intellectual curiosity, it is worth noting that neither Williamson nor Carolene Products created the rational basis test from whole cloth. Although the term "rational basis" was certainly in the legal lexicon before Carolene Products, ${ }^{31}$ the "more commonly used test" in the pre-Carolene era searched for a "reasonable" basis. Despite sharing similar phraseology and other similar features, ${ }^{32}$ the modern rational basis test "is not the same as the pre-1937 reasonable basis test." 33

Used in the late 1800s and early 1900s, the classical reasonable basis test, rooted primarily in conceptions of balance between traditional state

29. Beach, 508 U.S. at 315 ; see also id. ("[B] ecause we never require a legislature to articulate its reasons for enacting a statute, it is entirely irrelevant for constitutional purposes whether the conceived reason for the challenged distinction actually motivated the legislature. . . ."); Heller v. Doe, 509 U.S. 312, 320 (1993) ("A State ... has no obligation to produce evidence to sustain the rationality of a statutory classification . . . . A statute is presumed constitutional . . . and " $\mathrm{t}]$ he burden is on the one attacking the legislative arrangement to negative every conceivable basis which might support it . . . "' (second alteration in original) (citations omitted) (quoting Lenhausen, 410 U.S. at 364))); Minnesota v. Cloverleaf Creamery Co., 449 U.S. 456, 464 (1981) ("[Challengers] must convince the court that the legislative facts on which the classification is apparently based could not reasonably be conceived to be true by the governmental decisionmaker." (quoting Vance v. Bradley, 440 U.S. 93, 111 (1979))); McGowan v. Maryland, 366 U.S. 420, 426 (1961) ("A statutory discrimination will not be set aside if any state of facts reasonably may be conceived to justify it.").

30. Beach, 508 U.S. at 323 n.3 (Stevens, J., concurring).

31. See, e.g., Metro. Cas. Ins. Co. of N.Y. v. Brownell, 294 U.S. 580, 584 (1935); James M. McGoldrick, Jr., The Rational Basis Test and Why It Is So Irrational: An Eighty-Year Retrospective, 55 SAn Diego L. Rev. 751, 762 (2018) [hereinafter McGoldrick, Jr., Retrospective].

32. Jackson, Classical, supra note 8, at 497.

33. McGoldrick, Jr., Retrospective, supra note 31, at 762. Courts arguably still apply the reasonable basis test in certain limited situations, including cases involving the fundamental rights of prisoners, content-neutral regulation of speech, searches of students by teachers and school officials, and classifications based on illegitimacy. See id. (first citing Turner v. Safley, 482 U.S. 78, 87 (1987); then citing Cornelius v. NAACP Legal Def. \& Educ. Fund, Inc., 473 U.S. 788, 800 (1985); and then citing New Jersey v. T.L.O., 469 U.S. 325, 341-42 (1985); Lalli v. Lalli, 439 U.S. 259, 265 (1978)). Courts sometimes also deploy a more rigorous rational basis test, often referred to as rational basis with "bite." See id. (citing Jeremy B. Smith, The Flaws of Rational Basis with Bite: Why the Supreme Court Should Acknowledge Its Application of Heightened Scrutiny to Classifications Based on Sexual Orientation, 73 ForDHAm L. Rev. 2769, 2774 (2005)); see also Romer v. Evans, 517 U.S. 620, 631-32 (1996); City of Cleburne v. Cleburne Living Ctr., Inc., 473 U.S. 432, 447-48 (1985); Zobel v. Williams, 457 U.S. 55, 61, 63 (1982); U.S. Dep't of Agric. v. Moreno, 413 U.S. 528, 538 (1973). 
police power and federal constitutional constraints, ${ }^{34}$ undertook a more searching review of at least state legislative action. In most cases, courts did not uphold legislation based on "conceived" or speculated facts-but instead examined reality. "If . . . a statute purporting to have been enacted to protect the public health, the public morals, or the public safety, has no real or substantial relation to those objects," the Supreme Court pronounced in 1887, "it is the duty of the courts to so adjudge, and thereby give effect to the Constitution." 35

Even though "far more legislation was upheld than struck down" under the reasonable basis test, ${ }^{36}$ many criticized the test as insufficiently deferential to legislative will. ${ }^{37}$ One prominent critic was Justice Oliver Wendell Holmes, Jr., who through the lens of broad judicial restraint embraced "the right of a majority to embody their opinions in law." 38 Dissenting in Lochner, for instance, Holmes opined that

the word "liberty" in the Fourteenth Amendment is perverted when it is held to prevent the natural outcome of a dominant opinion, unless it can be said that a rational and fair man necessarily would admit that the statute proposed would infringe fundamental principles as they have been understood by the traditions of our people and our law. ${ }^{39}$

The full Court eventually got on the Holmesian bandwagon. "The modern rational basis test," Jeffrey Jackson has observed, "purports to be a correction to what are perceived to be the excesses of the Court (and also lower courts) during the first three decades of the 1900s." ${ }^{0}$ The purported correction shines brightly in the Williamson Court's triumphant proclamation that " $[\mathrm{t}]$ he day is gone when this Court uses the Due Process

34. Jackson, Classical, supra note 8, at 497. See generally Howard Gillman, The Constitution Besieged 45-60, 64-75 (1993).

35. Mugler v. Kansas, 123 U.S. 623, 661 (1887). But see Lindsley v. Nat. Carbonic Gas Co., 220 U.S. 61, 78 (1911) ("[I]f any state of facts reasonably can be conceived that would sustain it, the existence of that state of facts . . must be assumed.").

36. Jackson, Classical, supra note 8, at 499; Ray A. Brown, Due Process of Law, Police Power, and the Supreme Court, 40 Harv. L. Rev. 943, 944 (1927) (“[T] he Court had decided under the due process clause ninety-eight cases involving substantive legislation of a social or economic character, and in only six of these did the Court hold the legislation unconstitutional."); Charles Warren, The Progressiveness of the United States Supreme Court, 13 Colum. L. Rev. 294, 295 (1913) ("Examination of .. 560 cases [decided between 1887 and 1911] conclusively proves that the alleged evil in the trend of the Court is a purely fancied one; for out of these 560 cases there are only two cases ... in which any State law, involving a social or economic question of the kind included under the phrase 'social justice' legislation, has been held unconstitutional by the Supreme Court.").

37. David E. Bernstein, Rehabilitating Lochner 40-55 (2011).

38. Lochner v. New York, 198 U.S. 45, 75-76 (1905) (Holmes, J., dissenting); see Yosal Rogat, The Judge as Spectator, 31 U. CHI. L. Rev. 213, 243-56 (1964).

39. Lochner, 198 U.S. at 75-76 (Holmes, J., dissenting).

40. Jackson, Classical, supra note 8, at 500. 
Clause of the Fourteenth Amendment to strike down state laws, regulatory of business and industrial conditions, because they may be unwise, improvident, or out of harmony with a particular school of thought." 41 Williamson "adopted Holmes's rational basis test as the standard" 42 and in turn "render[ed] the precise coordinates" of legislative judgment "virtually unreviewable." 43

As a purported correction to perceived overzealous judicial policing of economic regulation (epitomized by Lochner), the modern rational basis test is most often used to review federal and state statutes regulating or prohibiting economic conduct. The Supreme Court has "made clear" that when "ordinary commercial transactions are at issue, rational basis review requires deference to reasonable underlying legislative judgments." ${ }^{44}$ To that end, the Court has employed the deferential rational basis test to review federal and state economic legislation under the due process and equal protection guarantees of both the Fifth and Fourteenth Amendments. ${ }^{45}$ It has also used the test in regulatory takings cases ${ }^{46}$ and to review statutes for consistency with the Commerce Clause. ${ }^{47}$

41. Williamson v. Lee Optical, 348 U.S. 483, 488 (1955); see also Ferguson v. Skrupa, 372 U.S. 726, 731-32 (1963) ("We refuse to sit as a "superlegislature to weigh the wisdom of legislation,' and we emphatically refuse to go back to the time when courts used the Due Process Clause 'to strike down state laws, regulatory of business and industrial conditions, because they may be unwise, improvident, or out of harmony with a particular school of thought." (first quoting Day-Bright Lighting, Inc., v. Missouri, 342 U.S. 421 (1952); then quoting Williamson, 348 U.S. at 488$)$ ).

42. Melvin I. Urofsky, Dissent and the Supreme Court: Its Role in the Court's History and the Nation's Constitutional Dial 155 (2015).

43. FCC v. Beach Commc'ns, Inc., 508 U.S. 307, 316 (1993); see also Williamson, 348 U.S. at 488 (quoting Munn v. Illinois, 94 U.S. 113, 134 (1877) ("For protection against abuses by legislatures the people must resort to the polls, not the courts.").

44. Armour v. City of Indianapolis, 566 U.S. 673, 680 (2012) (quoting United States v. Carolene Prods. Co., 304 U.S. 144, 152 (1938)).

45. Astrue v. Capato ex rel. B.N.C., 566 U.S. 541 (2012) (upholding provisions of federal Social Security Act allegedly violating equal protection); Armour, 566 U.S. 673 (upholding city sewer assessment allegedly violating equal protection); Fitzgerald v. Racing Ass'n of Cent. Iowa, 539 U.S. 103 (2003) (upholding Iowa taxation scheme, which taxed racetrack slot-machine revenue differently from riverboat slot-machine revenue, over equal-protection challenge); Williamson, 348 U.S. 483 (upholding Oklahoma law allegedly violating due process and equal protection); Carolene Prods., 304 U.S. 144 (upholding federal law allegedly violating due process).

46. See Kelo v. City of New London, 545 U.S. 469 (2005)) ("When the legislature's purpose is legitimate and its means are not irrational, our cases make clear that empirical debates over the wisdom of takings-no less than debates over the wisdom of other kinds of socioeconomic legislation-are not to be carried out in the federal courts." (quoting Haw. Hous. Auth. v. Midkiff, 467 U.S. 229, 242-43 (1984))); see also Midkiff, 467 U.S. at 241 (holding that "the exercise of . . eminent domain power" will be upheld if it "is rationally related to a conceivable public purpose").

47. United States v. Lopez, 514 U.S. 549 (1995) (striking down federal statute on Commerce Clause grounds, albeit only arguably applying the rational basis 
Yet the Supreme Court has also applied the rational basis test beyond the economic context. Generally speaking, the test is used whenever a statute implicates neither a fundamental right nor a suspect classification. In Vacco v. Quill, ${ }^{48}$ for example, the Court applied the rational basis test to uphold a New York statute banning assisted suicide. ${ }^{49}$ Similarly in Central State University v. American Association of University Professors, ${ }^{50}$ the Court applied the test to uphold an Ohio workload-requirement statute designed to increase public-university faculty members' weekly teaching hours. ${ }^{51}$ And in Abigail Alliance v. Eschenbach, ${ }^{52}$ the District of Columbia Circuit applied the test to uphold an FDA regulation prohibiting the sale of certain experimental drugs to terminally ill patients. ${ }^{53}$ Although this Article focuses primarily on legislative action, the Supreme Court has also applied the test to other forms of government action. Recently in Trump v. Hawaii, ${ }^{54}$ for example, plaintiffs challenged a presidential proclamation restricting entry of certain foreign nationals into the United States, alleging that it violated the Establishment Clause. The Court applied the rational basis test and upheld the proclamation. ${ }^{55}$

test); Carolene Prods., 304 U.S. at 152 (upholding federal law under the Commerce Clause). With respect to the Commerce Clause, "[1] aws that intentionally or facially discriminate against outsiders or against interstate commerce are subject to strict scrutiny, while those that are facially neutral are subject to minimal scrutiny." Sherry, supra note 17, at 560. In Justice Anthony Kennedy's opinion, the Supreme Court's rational basis test in Commerce Clause cases differs from its test in equalprotection and due-process cases; whereas in the latter the Court requires only conceivable facts, in the former the Court requires a showing of actual empirical facts. See United States v. Comstock, 560 U.S. 126, 151-54 (2010) (Kennedy, J., concurring) ("The rational basis referred to in the Commerce Clause context is a demonstrated link in fact, based on empirical demonstration. While undoubtedly deferential, this may well be different from the rational basis test as Lee Optical described it.").

48. 521 U.S. 793 (1997).

49. Id. at 808-09.

50. 526 U.S. 124 (1999).

51. Id. at 128. Although the majority opinion omits any discussion of a standard of review, many consider United States $v$. Windsor, 133 S. Ct. 2675 (2013), to be a rational basis case. See Farrell, Equal Protection, supra note 18, at 452-55. Windsor struck down part of the federal Defense of Marriage Act and was "based entirely on the fact that the challenged classification seeks to advance an impermissible purpose-animosity toward a particular group. The Court made no attempt to consider other permissible purposes that the law might have advanced." Id.

52. 495 F.3d 695 (D.C. Cir. 2007).

53. Id. at 712-13; see also, e.g., Box v. Planned Parenthood of Ind. \& Ky., Inc., 139 S. Ct. 1780, 1781-82 (2019) (holding that state abortion regulation was supported by a rational basis); Village of Willowbrook v. Olech, 528 U.S. 562 (2000) (holding that no rational basis existed for village's demand of a 33-foot easement from plaintiff to connect her house to the public water supply, but only a 15 -foot easement from other property owners).

54. 138 S. Ct. 2392 (2018).

55. Id. at 2420-23. 


\section{Constitutional Principles}

In this Article, I ultimately argue that the rational basis test, as described above, is inconsistent with the U.S. Constitution. This Part discusses the constitutional provisions and principles underlying my ultimate argument. First, I explain the Constitution's structural separation of powers, including the historical backdrop that led to its adoption. Second, I explain what one of the three constitutionally separated powers-the "judicial power," vested in the federal courts-means and entails. Third, I discuss the Supremacy Clause, which establishes the primacy of federal law over state law and the U.S. Constitution over all contrary law.

\section{A. Separation of Powers}

Western philosophy and political theory have long recognized three types of human power, exercisable by both individuals and collectives: will, force, and judgment. ${ }^{56}$ These powers find political expression as legislative power, executive power, and judicial power, respectively. In most governments throughout history, at least two-and often all three-of those powers have been amalgamated in single actors or bodies. Against that backdrop, John Locke lamented that "it may be too great a temptation to human frailty, apt to grasp at [p] ower, for the same persons who have the [p] ower of making laws to have also in their hands the power to execute them." 57

From Ancient Greece through Blackstone's England and beyond, philosophers and political theorists have recognized that "[a] government of diffused powers . . . is a government less capable of invading the liberties of the people." ${ }^{58}$ No single person has had more influence in expounding and popularizing separation-of-powers theory than the French philosopher Montesquieu. ${ }^{59} \mathrm{He}$ was arguably the first, and certainly the most prominent, theorist to articulate the importance of a tripartite division of authority. ${ }^{60}$ Separating will from force and both from judgment became

56. See Philip Hamburger, Is Administrative Law Unlawful? 326-28 (2014) [hereinafter HAMBURGER, UNLAWFUL].

57. John Locke, The Second Treatise of Civil Government $\$ 143$ (1764), reprinted in Two Treatises of Government 119, 194 (Thomas I. Cook ed. 1947).

58. Gutierrez-Brizuela v. Lynch, 834 F.3d 1142, 1149 (10th Cir. 2016) (Gorsuch, J., concurring); see also Cynthia R. Farina, Statutory Interpretation and the Balance of Power in the Administrative State, 89 Colum. L. Rev. 452, 488-89 (1989).

59. See Gerhard Casper, An Essay in the Separation of Powers: Some Early Versions and Practices, 30 WM. \& Mary L. Rev. 211, 213 (1989) (describing Montesquieu as "the most frequently cited" theorist of the separation of powers); Farina, supra note 58, at 488-90 (discussing Montesquieu's influence on Founding Era separation-ofpowers thought).

60. John F. Manning, Constitutional Structure and Judicial Deference to Agency Interpretations of Agency Rules, 96 Colum. L. Rev. 612, 645 n.163 (1996) [hereinafter Manning, Constitutional Structure] (citing William B. Gwyn, The Meaning of the Separation of Powers 101-02 (1965)). 
understood as "essential to the preservation of liberty" 61 and the promotion of the rule of law ${ }^{62}$-or, as Philip Hamburger has helpfully stressed, rule under and through law. ${ }^{63}$

Philosophical developments advocating for the separation of powers were paralleled by political events demanding such separation. These parallels appeared first in revolutionary England as a reaction against the Crown's prerogative courts. They later continued in revolutionary America as a reaction against the Crown generally and colonial and early state legislatures specifically. ${ }^{64}$ The U.S. Constitution was (and is) seen as an attempt to rectify pre-constitutional excesses and liberty deprivations resulting from incomplete separation. ${ }^{65}$

Borrowing heavily from Montesquieu-who Madison called the "oracle" of separation-of-powers philosophy ${ }^{66}$ - the Framers wrote at length about the separation of powers. As Publius, Madison captured the contemporaneous (and timeless) angst "that power is of an encroaching nature." 67 "The accumulation of all powers, legislative, executive, and judiciary, in the same hands, whether of one, a few, or many," he subsequently added, "may justly be pronounced the very definition of tyranny." ${ }^{2}$ With strident confidence, Madison concluded: "No political truth is . . stamped with the authority of more enlightened patrons of liberty" than the separation of powers. ${ }^{69}$

To that end, the Framers "built into the tripartite Federal Government ... a self-executing safeguard against the encroachment or aggran-

61. The Federalist No. 51, at 318 (James Madison) (Clinton Rossiter ed. 1961); Gutierrez-Brizuela, 834 F.3d at 1149 (Gorsuch, J., concurring). The separation of powers also protects liberty and guards against arbitrary governance by effectively requiring three branches to concur on the legitimacy of a government act. See, e.g., Raymond M. Kethledge, Hayek and the Rule of Law: Implications for Unenumerated Rights and the Administrative State, 13 N.Y.U. J.L. \& LibERTy 193, 212 (2020) ("The more important protection, instead, is the requirement that any particular act of coercion have the concurrence of three branches.").

62. See Manning, Constitutional Structure, supra note 60, at 645-47; see also M.J.C. Vile, Constitutionalism and the Separation of Powers 66, 102-06 (1967); Cass R. Sunstein, Constitutionalism After the New Deal, 101 Harv. L. REv. 421, 434 (1987).

63. See Hamburger, Unlawful, supra note 56, at 7.

64. See id. at 323-54; Manning, Constitutional Structure, supra note 60, at 640-42; see also Forrest McDonald, Novus Ordo Seclorum 143-83 (1985); 2 The Records of the Federal Convention of 1787 73, 74 (Max Farrand ed. 1966) (July 21, 1787) (remarks of James Madison) ("Experience in all the States had evinced a powerful tendency in the Legislature to absorb all power into its vortex."); id. at 76 (Gouverneur Morris "concurred in thinking the public liberty in greater danger from Legislative usurpations than from any other source.").

65. See Manning, Constitutional Structure, supra note 60, at 645-46 n.165.

66. The Federalist No. 47, supra note 61, at 301 (James Madison).

67. The Federalist No. 48, supra note 61, at 305 (James Madison).

68. The Federalist No. 47, supra note 61, at 298 (James Madison); see also The Federalist No. 48, supra note 61, at 305-09 (James Madison); The Federalist No. 51, supra note 61, at 317-21 (James Madison).

69. See The Federalist No. 47, supra note 61, at 298 (James Madison). 
dizement of one branch at the expense of the other." ${ }^{70}$ The "very structure" of the Constitution vests each of three branches of the federal government with distinct powers. ${ }^{71}$ First, the Constitution vests Congress with "the legislative power." 72 With this power of will, Congress "commands the purse" and "prescribes the rules by which the duties and rights of every citizen are to be regulated." ${ }^{3}$ Second, vested with "the executive power," 74 the President "dispenses the honors" and "holds the sword of the community." 75 Third and finally come the federal courts, in which the Constitution vests "the judicial power" 76 to "interpret[ ] the law and apply[ ] it retroactively to resolve past disputes." 77 Built on Montesquieu and necessitated by historical experience, the Constitution's tripartite organization "exemplifies the concept of separation of powers"78 and, in so doing, "diffuses power the better to secure liberty."

Because of the separation of powers' importance for safeguarding liberty, ${ }^{80}$ Justice Joseph Story considered it a "maxim of vital importance that the three great powers of government . . . forever be kept separate and distinct." 81 Although interest in patrolling inter-branch separation has waxed and waned over the nation's 250-year history, the Supreme Court

70. Clinton v. Jones, 520 U.S. 681, 699 (1997) (alteration in original) (internal quotation marks omitted) (quoting Buckley v. Valeo, 424 U.S. 1, 122 (1976)).

71. Miller v. French, 530 U.S. 327, 341 (2000) (quoting INS v. Chadha, 462 U.S. 919, 946 (1983)); see also Lujan v. Defenders of Wildlife, 504 U.S. 555, 559 (1992). Compare U.S. Const. art. I, with id. art. II, and id. art. III.

72. U.S. Const. art. I.

73. The Federalist No. 78, supra note 61, at 465 (Alexander Hamilton).

74. U.S. Const. art II.

75. The Federalist No. 78, supra note 61, at 465 (Alexander Hamilton). See generally Saikrishna Prakash, The Essential Meaning of Executive Power, 2003 U. ILL. L. REv. 701. "In the late-eighteenth century," when the Constitution was ratified, "someone vested with the executive power and christened as the chief executive enjoyed the power to control the execution of law." Id. at 819.

76. U.S. Const. art. III.

77. Gutierrez-Brizuela v. Lynch, 834 F.3d 1142, 1149 (10th Cir. 2016) (Gorsuch, J., concurring).

78. Miller v. French, 530 U.S. 327, 341 (2000) (citing INS v. Chadha, 462 U.S. 919, 946 (1983)); see also Humphrey's Ex'r v. United States, 295 U.S. 602, 629-30 (1935) ("So much is implied in the very fact of the separation the powers of these departments by the Constitution ....").

79. Youngstown Sheet \& Tube Co. v. Sawyer, 343 U.S. 579, 635 (1952) (Jackson, J., concurring).

80. Morrison v. Olson, 487 U.S. 654, 727 (1988) (Scalia, J., dissenting) ("The purpose of the separation and equilibration of powers in general was not merely to assure effective government but to preserve individual freedom."); supra notes 57-69 and accompanying text.

81. 2 Joseph Story, Commentaries on the Constitution of the United States $§ 519$, at 2-3 (Boston, Hilliard, Gray, \& Co., 1833). None of the branches, Madison stressed, "ought to possess, directly or indirectly, an overruling influence over the others, in the administration of their respective powers." THE FEDERALIST No. 48, supra note 61, at 305 (James Madison). 
has repeatedly recognized both the legal and political gravity of the Constitution's structural separation. ${ }^{82}$

\section{B. "Judicial Power"}

Article III of the Constitution places the federal judicial power in the hands of the federal courts: "The judicial power of the United States, shall be vested in one Supreme Court, and in such inferior courts as the Congress may from time to time ordain and establish." ${ }^{3}$ Nowhere does the Constitution define "judicial power," thus raising the question: what, exactly, is it?

The answer begins with what judicial power is not. Given the structural separation of powers implied by the Constitution's text and history, judicial power must differ from legislative power (will) and executive power (force). Bereft of both will and force, the judicial power captures the third form of human power: judgment. ${ }^{84}$ Broadly speaking, then, the judicial power can be thought of not as the power of will, and not as the power of force, but rather as the power to exercise judgment.

Likely the single most famous American expression of the judicial power comes from Chief Justice John Marshall's opinion in Marbury $v$. Madison. ${ }^{85}$ In identifying the judicial power with its holder, the judicial branch, Marshall explained that "[i]t is emphatically the province and duty of the judicial department to say what the law is." 86 Without more, however, one might dismiss that statement as begging the question-or worse, Clintonian wordplay. ${ }^{87}$ Yet the power-the "province and duty"to "say what the law is" very neatly captures the essence of the judicial power.

The power to "say what the law is" includes three interrelated, but conceptually separable, elements. First, with the judicial power, courts exercise judgment to apply law (often general rules of conduct in the form of legislation) to particular disputes. Second, as a necessary part of doing so, courts interpret what the law means. Third, courts resolve conflicts

82. " $[\mathrm{S}]$ itting atop the judicial branch, this Court has always carried a special duty to 'jealously guar[d]' the Constitution's promise of judicial independence. So we have long resisted any effort by the other branches to "usurp a court's power to interpret and apply the law to the circumstances before it." Kisor v. Wilkie, 139 S. Ct. 2400, 2438 (2019) (Gorsuch, J. concurring) (second alteration in original) (footnote omitted) (first quoting Bank Markazi v. Peterson, 136 S. Ct. 1310, 1323 (2016); then quoting N. Pipeline Constr. Co. v. Marathon Pipe Line Co., 458 U.S. 50, 60 (1982) (plurality opinion)). Regarding waxing and waning patrolling, see, for example, Ronald J. Krotoszynski \& Atticus DeProspro, Against Congressional Case Snatching, 62 WM. \& Mary L. Rev. 791, 812-17 (2021).

83. U.S. Const. art. III $§ 1$.

84. See The Federalist No. 78, supra note 61, at 464 (Alexander Hamilton). 85. 5 U.S. (1 Cranch) 137 (1803).

86. Id. at 177 .

87. President Bill Clinton once told a grand jury: "It depends upon what the meaning of the word 'is' is." H.R. Doc. No. 105-310, at 176 (1998). 
between multiple conflicting sources of law. Each one of these elements of judicial power may initially sound unremarkable and even unnecessary to mention. Although they are ingrained and assumed in modern American public and legal consciousness, they nevertheless each bear significant meaning, as the balance of this Section expounds.

Whereas the legislative power of will entails the authority to establish rules of conduct generally and prospectively, the judicial power of judgment entails the application of those general rules to specific parties in particular disputes. ${ }^{88}$ Likewise, whereas the executive power entails the use of physical force, the judicial power includes only the power of judgment-which, in turn, can be carried into effect by an executive actor. ${ }^{89}$

As a natural and unavoidable consequence of applying general rules to specific cases, courts exercising judgment must also interpret the rules' meanings. Chief Justice Marshall explained this in Marbury, stating that " $[t]$ hose who apply the rule to particular cases, must of necessity expound and interpret that rule." 90 The judicial power, then, necessarily includes the power and duty to interpret the law. Moreover, because the federal judicial power belongs to the courts and is separated from the other branches, " $[\mathrm{t}]$ he interpretation of the laws is the proper and peculiar province of the courts." 91 As Justice Thomas recently reiterated, "the judicial power, as originally understood, requires a court to exercise its independent judgment in interpreting and expounding upon the laws." 92

Interpreting and expounding upon the laws entails deciding on meaning, resolving ambiguities, and ultimately reaching conclusions-on a case-by-case basis-about the best, fairest, and correct meaning of the law. By exercising their power of independent judgment, courts in any given case must ascertain the "best and fairest" interpretation of the law. ${ }^{93}$ Even though close cases exist and reasonable judges may disagree, courts

88. Gutierrez-Brizuela v. Lynch, 834 F.3d 1142, 1149 (10th Cir. 2016) (Gorsuch, J., concurring).

89. See The Federalist No. 78, supra note 61, at 464 (Alexander Hamilton) ("The judiciary ... has no influence over either the sword or the purse, no direction either of the strength or of the wealth of the society, and can take no active resolution whatever. It may truly be said to have neither Force nor Will, but merely judgment; and must ultimately depend upon the aid of the executive arm even for the efficacy of its judgments.").

90. Marbury, 5 U.S. at 177.

91. The Federalist No. 78, supra note 61, at 467 (Alexander Hamilton). The judicial power "belongs to [judges] to ascertain . . . the meaning of any particular act proceeding from the legislative body." Id.

92. Baldwin v. United States, 140 S. Ct. 690, 691 (2020) (mem.) (Thomas, J., dissenting from denial of certiorari) (quoting Perez v. Mortg. Bankers Ass'n, 575 U.S. 92, 119 (2015) (Thomas, J. concurring)).

93. Kisor v. Wilkie, 139 S. Ct. 2400, 2429-30 (2019) (Gorsuch, J., concurring); accord, e.g., Michigan v. EPA, 135 S. Ct. 2699, 2712 (2015) (Thomas, J., concurring); Gutierrez-Brizuela, 834 F.3d at 1152, 1155-56 (Gorsuch, J., concurring). By the same token, ascertaining the best, fairest, and correct interpretation of the law in a particular case does not mean the court determines a law's meaning and applicability in all cases. 
nevertheless are entrusted to "reach conclusions about the meaning of statutes, rules of procedure, contracts, and the Constitution," and indeed, all sources of law. ${ }^{94}$ " $[\mathrm{N}]$ o matter how closely balanced the question may seem to be," Justice Antonin Scalia once wrote, "[t]he judicial task, every day, consists of finding the right answer." ${ }^{5}$

One can envision this judicial task of interpretation graphically. In Figure A below, the solid horizontal line represents all possible interpretations of a law or legal text. In a particular case, a court exercises judicial power to ascertain the best, fairest, and correct interpretation; doing so is a process of convergence into a single meaning in a particular case. This process is represented by converging dotted lines, and that result is represented by a "line of correctness."

Figure A

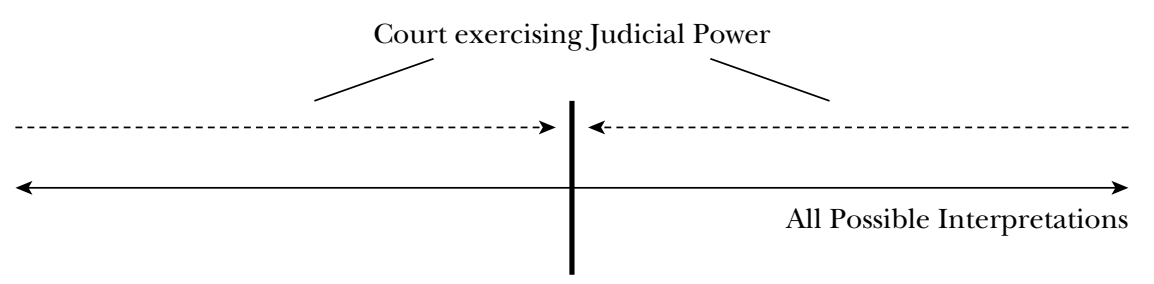

Line of Correctness

(Best, Fairest, Correct Interpretation)

Sometimes, of course, a law might be ambiguous or vague. Fully familiar with ambiguity, the Framers "understood the judicial power to include the power to resolve these ambiguities," 96 and "the interpretation of legal texts, even vague ones, remained an exercise of core judicial power." 97 No less than with unambiguous laws, "[c] ourts were expected" to apply such vague or ambiguous laws, clarifying their meaning "over time as they applied their terms to specific cases." 98 Just because a law is ambiguous or vague, in other words, does not alter the nature of the judicial power or place it in the hands of a different branch.

94. Kisor, 139 S. Ct. at 2430 (Gorsuch, J., concurring) (emphasis added).

95. Antonin Scalia, Judicial Deference to Administrative Interpretations of Law, 1989 Duke L.J. 511, 520 (1989).

96. Baldwin, 140 S. Ct. at 691 (mem.) (Thomas, J., dissenting from denial of certiorari) (quoting Perez, 575 U.S. at 119 (Thomas, J., concurring in the judgment)).

97. Sessions v. Dimaya, 138 S. Ct. 1204, 1249 (2018) (Thomas, J., dissenting); see id. at 1232 (Gorsuch, J., concurring in part); Perez v. Mortg. Bankers Ass'n, 135 S. Ct. 1199, 1217 (Thomas, J., concurring in judgment); 1 William Blackstone, Commentaries on the Laws of England 88 (Garland Publ'g 1978) (1765); Philip Hamburger, The Constitution's Accommodation of Social Change, 88 MicH. L. REv. 239, 303-10 (1989) [hereinafter Hamburger, Accommodation].

98. Dimaya, 138 S. Ct. at 1250 (2018) (Thomas, J., dissenting) (first citing Hamburger, Accommodation, supra note 97, at 303-10; then citing Caleb Nelson, Originalism and Interpretive Conventions, 70 U. ChI. L. Rev. 519, 526 (2003)). 
Although I return to this theme throughout the balance of the Article, it is worth briefly commenting now on the interaction of the judicial power and the separation of powers. By vesting a particular branch with the judicial power, the Constitution communicates that other branches may not exercise the judicial power. For instance, Congress has no authority to conclusively interpret the statutes it enacts or to adjudicate cases, outside of making new laws. ${ }^{99}$ Nor does the President have either power. To be sure, the political branches may tailor their actions to conform with the Constitution; their individual officers must do so to uphold their constitutional oath. That said, the courts invariably act as final arbiter of the law's meaning. "[I]t is not to be forgotten," Justice Joseph Story emphasized, "that the [J]udicial [D] epartment has imposed upon it by the constitution, the solemn duty to interpret the laws, in the last resort." 100 No matter how "disagreeable that duty may be," Story added, the separation of powers demands that even in cases where a court's "own judgment shall differ from that of other high functionaries," the court "is not at liberty to surrender, or to waive" its duty or its judicial power. ${ }^{101}$ "[A] permanent and indispensable feature of our constitutional system" is that "the federal judiciary is supreme in the exposition of the law of the Constitution." 102

99. See generally Patchak v. Zinke, 138 S. Ct. 897 (2018); United States v. Klein, 80 U.S. (13 Wall.) 128 (1872). added).

100. United States v. Dickson, 40 U.S. 141, 162 (1841) (Story, J.) (emphasis

101. Id.

102. Miller v. Johnson, 515 U.S. 900, 922-23 (1995) (quoting Cooper v. Aaron, 358 U.S. 1, 18 (1958)). Indeed, it is a "basic principle that the federal judiciary is supreme in the exposition of the law of the Constitution, and that principle has ever since been respected by this Court and the Country as a permanent and indispensable feature of our constitutional system." Cooper, 358 U.S. at 18; see also, e.g., Planned Parenthood v. Casey, 505 U.S. 833, 868 (1992); United States v. Nixon, 418 U.S. 683, 703-05 (1974); Powell v. McCormack, 395 U.S. 486, 549 (1969); Baker v. Carr, 369 U.S. 186, 211 (1962); see also infra notes 260-65 and accompanying text. "Madison and his contemporaries expected the practice that developed under the Constitution to 'liquidate and settle the meaning' of . . . contestable [constitutional] provisions." Nelson, supra note 98, at 527 (quoting Letter from James Madison to Spencer Roane (Sept. 2, 1819), in 3 LetTers of Madison 143, 145); The Federalist No. 82, supra note 61, at 490 (Alexander Hamilton); The Federalist No. 37, supra note 61, at 224-25 (James Madison). On the one hand, even Madison thought liquidation of meaning was not necessarily limited to judicial liquidation. On the other hand, just because other branches may play a role in expositing the law over time does not change the judiciary's power and duty to exercise independent judgment and to fully ascertain meaning in particular cases. See Letter from James Madison to Spencer Roane, supra, at 143 ("I have always supposed that the meaning of a law, and . . of a constitution, so far as it depends on judicial interpretation, was to result from a course of particular decisions, and not those from a previous and abstract comment on the subject."). But cf. Nelson, supra note 98, at 597 (noting how "various commentators have suggested that members of the political branches should play a greater role in liquidating at least some of the Constitution's indeterminacies than members of the federal judiciary"); Frank Easterbrook, Abstraction and Authority, 59 U. CHI. L. Rev. 349, 374-75 (1992) ("If the age or generality of the text frustrates the statement of a rule, then it also defeats the claim of judicial power. If the living must indeed 
As just quoted, Justice Story referred to the federal judiciary's "duty." So too did Chief Justice Marshall in Marbury, stating that "[i]f two laws conflict with each other, the courts must decide on the operation of each." 103 Judicial power, it has been long accepted, implies judicial duty. ${ }^{104}$ "[W] hen the Constitution authorized judicial power, it took for granted that judges, by their nature," have a "duty" to "exercise independent judgment in accord with the law of the land." 105 The judicial duty, which "accompanies judicial power," 106 includes everything already discussed, as well as one more critical component. In addition to ascertaining meaning, the judicial power and its concomitant duty require courts to resolve conflict between multiple applicable sources of law.

English law long understood the judicial power to impose a duty to decide in accord with higher law. ${ }^{107}$ Indeed, "[s]ince classical and early Christian times, it had been suggested that acts were lawful only if they conformed to superior law." 108 English lawyers were fully "[a]ccustomed to thinking about law within a hierarchy, and to understanding this hierarchy as the primary source of legal obligation," and, to that end, "could not help but be aware that a superior law determined the lawfulness of an inferior law and thus might render it unlawful and therefore void." 109 Recognizing and respecting a hierarchy of law is endemic to the judicial power and judicial duty. Where multiple sources of law apply in a given case and those sources conflict, the judicial power entails-and the judicial duty requires-deciding in accord with the higher-order law.

The power and duty to decide in accord with higher-order law forms the basis of what is now referred to as judicial review. "Judicial review," as Philip Hamburger has put it, "is entailed by judicial duty." 110 Despite what many believe, judicial review was neither an American invention nor a power grab by the Marshall Court. It was rather a "broader phenomenon than commentators on its history have recognized," resting not necessarily on any particular constitutional provision but rather "in the context of general assumptions about law and judicial duty-about the hierarchical character of law and the duty of judges to decide in accord with law." 111 In exercising their power of judgment to apply law to adjudicate cases, for

chart their own course, then the question is political, outside the domain of judicial review.").

103. Marbury v. Madison, 5 U.S. (1 Cranch) 137, 177 (1803).

104. See generally Philip Hamburger, Law and Judicial Duty (2008) [hereinafter Hamburger, LAw].

105. Hamburger, Unlawful, supra note 56, at 312.

106. $I d$.

107. Blackstone, supra note 97.

108. Philip Hamburger, Law and Judicial Duty, 72 Geo. Wash. L. Rev. 1, 9 (2003) [hereinafter Hamburger, Judicial Duty].

109. Id. at 12.

110. Hamburger, Unlawful, supra note 56, at 312.

111. Hamburger, Judicial Duty, supra note 108, at 2. See generally Hamburger, LAw, supra note 104; HAMBURger, UnLAWful, supra note 56. 
example, English courts in the Middle Ages began to review lower-order law for consistency with higher-order law. And it was " $[\mathrm{o}] \mathrm{n}$ the basis of their duty to decide in accord with law and their assumptions about the hierarchical character of law" that these courts "reviewed government acts." 112 In particular, those courts long possessed the power to review Crown action for consistency with English constitutional law-and to declare the former void where it violated the latter. ${ }^{113}$

One thing English courts did not have the authority to do, however, was review Parliamentary legislation for consistency with the English Constitution. Yet that lack of authority had nothing to do with the nature or definition of judicial power. It rather resulted from the organizational structure of English government and which bodies held which parts of the judicial power. Parliament was both the highest legislative body and the highest judicial body. English inferior courts lacked power to review Parliamentary acts, because Parliament as high court (the House of Lords) had already effectively passed on the constitutionality of its statutes by enacting them in its dual role as high legislator.

Although the meaning of "judicial power" in America derives directly from English tradition and history, the exercise of that power differs in America. "After 1776, American judges," following their English forebears, "continued the practice of evaluating acts for their lawfulness." 114 The "judicial power" vested in the federal courts carries the same meaning as the "judicial power" generally understood in English law for centuries: the power and duty to decide cases in accord with law, including the power to review lower-order law for consistency with higher-order law. In 1803, Chief Justice Marshall called it "the very essence of judicial duty" to decide which of two conflicting laws governs in a particular case. ${ }^{115}$

But unlike the organization of government in England, the U.S. Constitution organizes the American federal government differently. Instead of combining high court with high legislature, the Constitution separates the courts from Congress completely and vests the judicial power in the former but not the latter. ${ }^{116}$ Because of the tripartite separation of powers, exercising the judicial power in America also includes the power to review statutes: ${ }^{117}$

112. Hamburger, Judicial Duty, supra note 108, at 40.

113. Id. at $12-17$.

114. $I d$. at 18 .

115. Marbury v. Madison, 5 U.S. (1 Cranch) 137, 178 (1803).

116. See Hamburger, Judicial Duty, supra note 108, at 22. Hamburger also considers it critically important to the distinction between English and American government that "American constitutions were express acts of the people." Id. at 21.

117. See id. at 22-23. Although Article III vests the judicial power in "[c] ourts," judges matter for this analysis, too:

There were layers to the judges' obligation to perform this duty. To some extent, the obligation, like the duty, followed from the office, but unlike the duty, the obligation arose principally from the oath by which judges qualified for their office. More remotely, to the extent their office was 
What changed in America was not the invention of judicial review (which had been commonplace since at least the Middle Ages), nor even judicial review under a constitution (which was understood from at least the seventeenth century), nor even judicial review of legislation (which was familiar from the review of corporate and colonial acts). Instead, what was new in America was review under express constitutions and especially the review of the legislation of sovereign states. Otherwise, however, there was much continuity-most generally in the old assumption that an act could not lawfully violate a superior law and that judges were obliged by their office and their oaths to decide in accord with law. ${ }^{118}$

Contrary to popular belief, then, neither the U.S. Constitution nor Marbury invented judicial review or altered the judicial power or judicial duty. ${ }^{119}$ Instead, the American difference in the exercise of judicial power resulted from the Constitution's tripartite structure, meaning "judges now were free and even obliged to review legislative acts." 120

defined by law and their oaths were imposed by law, the judges could be considered legally obliged to decide in accord with law, and therefore judicial review could be described in terms of the judges' own legal duties. Most generally, to the extent judges had a duty to decide in accord with law, they were thereby bound by law, and presumably it was in this sense that the Supremacy Clause of the U.S. Constitution recited that state court judges were "bound" by federal law. Judges, however, typically were too cautious simply to say that in making their decisions, they were bound by law-perhaps because they hesitated to describe their duties in a manner that might seem to suggest that a judge's error amounted to a violation of law.

$I d$. at 24. (footnote omitted).

118. Id. at 18 .

119. Id. at 26; see also HAMBURger, LAw, supra note 104, at 1-2. In addition to Hamburger's extensive historical evidence of judicial review, Randy Barnett has also explained how, as an original interpretive matter, "judicial power" includes the power of judicial review of government action, both executive and legislative. See Randy E. Barnett, The Original Meaning of the Judicial Power, 12 Sup. CT. Econ. Rev. 115, 117 (2004) [hereinafter Barnett, Judicial Power]; see also Saikrishna B. Prakash \& John C. Yoo, The Origins of Judicial Review, 70 U. CHI. L. Rev. 887 (2003). Exhaustively chronicling Founding Era evidence of meaning, Barnett has concluded that "the original meaning of the 'judicial power' in Article III, included the power of judicial nullification." Barnett, Judicial Power, supra, at 117.

The evidence from the Constitutional Convention and from the state ratification conventions is overwhelming that the original public meaning of the term "judicial power" included the power to nullify unconstitutional laws. In contrast, because the "executive power" did not include the inherent power to veto legislation, it had to be added expressly.

Id. at 138 .

120. Hamburger, Judicial Duty, supra note 108, at 26. 


\section{Supremacy Clause}

The preceding Section explains how the judicial power entrusts courts with a duty to respect legal hierarchies; when lower-order law conflicts with higher-order law, the latter prevails. So, what is the hierarchy of law? The Supremacy Clause of the U.S. Constitution supplies answers:

This Constitution, and the Laws of the United States which shall be made in Pursuance thereof; and all Treaties made, or which shall be made, under the Authority of the United States, shall be the supreme Law of the Land; and the Judges in every State shall be bound thereby, any Thing in the Constitution or Laws of any State to the Contrary notwithstanding. ${ }^{121}$

As its text lays bare, this clause sets forth what sources of law constitute the "supreme Law of the Land." That supreme law consists of: (a) the U.S. Constitution, (b) certain statutes, and (c) certain treaties. ${ }^{122}$ Federal statutes are "Laws of the United States." Not all federal statutes (Laws of the United States) qualify as supreme law; only those Laws of the United States "made in Pursuance" of the U.S. Constitution achieve supreme status. This Article refers to such supreme statutes as "LOTUS-MIP."

The Supremacy Clause thereby establishes-or at least confirms-the legal hierarchy (1) between federal and state law, and (2) among different sources of federal law. First, it elevates certain federal law above contrary state law. By conscripting state judges to obey federal supreme law "notwithstanding" state law "to the Contrary," the Supremacy Clause ranks supreme law-including the U.S. Constitution and LOTUS-MIP-higher than contrary state constitutions and other sources of state law, including state statutes.

Second, the Supremacy Clause elevates certain federal law above other federal law. The U.S. Constitution and LOTUS-MIP reign supreme. This means, quite obviously, that the Constitution and LOTUS-MIP rank above federal administrative rules, which are not statutes (much less LOTUS-MIP). It also means, perhaps less obviously, that the Constitution ranks higher than all contrary statutes. If a law of the United States is "made in Pursuance" of the Constitution, then, by definition, it is consistent with the Constitution-and no question of hierarchy is presented. On the other hand, if a law of the United States is not "made in Pursuance" of the Constitution, then it does not qualify as supreme, and it ranks below the Constitution. To be "made in Pursuance," a statute must comply with the Constitution's procedural and substantive requirements ${ }^{123}$-and,

121. U.S. Const. art. VI.

122. Treaties are not relevant to this Article.

123. See Bradford R. Clark, The Supremacy Clause as a Constraint on Federal Power, 71 Geo. Wash. L. Rev. 91, 93-115 (2003); see also Hamburger, Unlawful, supra note 56, at 404-08; The Federalist No. 33, supra note 61, at 197-201 (Alexander Hamilton). After all, as Bradford Clark has observed, "[i]f all 'Laws' enacted by Congress qualified as 'the supreme Law of the Land,' then Congress and 
hence, the Constitution prevails over federal statutes that fall short either procedurally or substantively. ${ }^{124}$

In setting forth these two hierarchies, the Supremacy Clause "upholds the written Constitution as the highest form of federal law"125 and pro-

the President could effectively amend the Constitution by ordinary legislation. This would contradict the spirit, if not the letter, of Article V, which establishes precise procedures to govern constitutional amendments." Clark, supra, at 114.

Still, some scholars have rejected that view, contending instead that "made in pursuance" requires only procedural propriety. See, e.g., Alexander M. Bickel, The Least Dangerous Branch: The Supreme Court at the Bar of Politics 1, 9 (2d ed. 1986) (" $[\mathrm{I}] \mathrm{t}$ fully meets all else that is compelling in the language of the clause simply to conclude that the proviso that only those federal statutes are to be supreme which are made in pursuance of the Constitution means that the statutes must carry the outer indicia of validity lent them by enactment in accordance with the constitutional forms. If so enacted, a federal statute is constitutional."); see also John Harrison, The Constitutional Origins and Implications of Judicial Review, 84 VA. L. Rev. 333, 346 n.48 (1998) ("At the least, that phrase alludes to the Article I, § 7 process, so that the clause applies only to those writings that have been duly adopted."); William Van Alstyne, A Critical Guide to Marbury v. Madison, 1969 Duke L.J. 1, 20 ("The phrase 'in pursuance thereof' might as easily mean 'in the manner prescribed by this Constitution,' in which case acts of Congress might be judicially reviewable as to their procedural integrity, but not as to their substance."). David Currie and others have suggested that the phrase "made in pursuance" was "meant to distinguish those made under the Articles of Confederation." David P. Currie, The Constitution in the Supreme Court: The First Hundred Years 1789-1888 72-73 (1985); see also Michael J. Klarman, How Great Were the "Great" Marshall Court Decisions?, 87 VA. L. Rev. 1111, 1119 (2001) (“'In Pursuance thereof' means 'after,' not 'consistent with.'”).

More broadly, some scholars have rejected the idea that the Supremacy Clause contemplates any hierarchy among federal sources of law. Larry Kramer, for example, has said that "the Framers clearly decided to adopt judicial review as a device for controlling state laws," but that "the power of courts to review federal legislation was left unaddressed." Larry D. Kramer, The Supreme Court, 2000 TermForeword: We the Court, 115 HaRv. L. REv. 4, 61, 67 (2001).

124. What's more, the Supremacy Clause's two separate hierarchies (federal over state, and U.S. Constitution over certain federal) interact: by "condition [ing] the supremacy of federal 'Laws' on their being 'made in Pursuance' of the Constitution," the Supremacy Clause also mandates that courts "prefer federal statutes to contrary state law only if the statutes themselves fall within the scope of Congress' enumerated powers." Clark, supra note 123, at 100. This interaction was on display in two of the Supreme Court's most celebrated cases: McCulloch v. Maryland, 17 U.S. (4 Wheat.) 316 (1819), and Gibbons v. Ogden, 22 U.S. (9 Wheat.) 1 (1824).

McCulloch is known for upholding the statute creating the Bank of the United States and rejecting Maryland's ability to assess a state tax on the Bank's operations. McCulloch thus upheld the primacy of federal law over state law. McCulloch, 17 U.S. (4 Wheat.) at 425-36. But in the course of reaching those conclusions, the McCulloch Court also first explained that the Bank statute would be supreme-and hence, preemptive of contrary state law-only if it had been enacted in pursuance of the constitution, which the Court held it had been. See id. at 405-11.

In Gibbons, likewise, the Court was faced with a conflict between a federal statute and a state statute. The Court was careful, however, to not automatically assume that the federal statute prevailed simply because of its federal nature. Rather, the Court first took time to address whether the federal statute was "made in pursuance" of the Constitution, such that it qualified for supreme status above contrary state law. See Gibbons, 22 U.S. (9 Wheat.) at 190-94, 210-11.

125. Clark, supra note 123, at 113-14. 
vides a foothold in the Constitution's text to fully implement the principles of judicial review and judicial duty discussed above. Background principles alone may have implied what the Supremacy Clause spells out: the U.S. Constitution is supreme above all federal and state law to the contrary. With this hierarchical framework in place, federal judges are enabled to discharge the judicial power and duty with clarity.

And that is precisely what Chief Justice Marshall did in Marbury, a case highlighting the interaction between the judicial power and the Supremacy Clause. In the course of deciding a particular dispute between Marbury and Madison, Marshall observed that both a federal statute and the U.S. Constitution supplied applicable law, but also that they conflicted. First, Marshall recalled the judicial power and its concomitant duty. "If two laws conflict with each other," he wrote, "the court must determine which of these conflicting rules governs the case." 126 He stressed that this task "is of the very essence of judicial duty." 127 Second, to fulfill this judicial duty, Marshall turned to the Supremacy Clause. "[I]n declaring what shall be the supreme law of the land," Marshall noted that "the constitution itself is first mentioned" and that "not the laws of the United States generally" rank supreme, "but those only which shall be made in pursuance of the constitution, have that rank."128 Reasoning from major premise (the judicial duty privileges higher-order law over contrary lower-order law) through minor premise (the Supremacy Clause elevates the U.S. Constitution above statutes), Marshall declared the Constitution "and no[ ] such ordinary act, must govern the case to which they both apply" because the Constitution is "a superior, paramount law." 129 Ultimately, Marshall concluded that "the particular phraseology of the constitution of the United States confirms and strengthens the principle, supposed to be essential to all written constitutions, that a law repugnant to the constitution is void; and that courts, as well as other departments, are bound by that instrument." 130

\section{Chevron Deference: The Analogy}

In this Part, I offer an analogy that will lay additional foundation for my constitutional critique of the rational basis test. Much like how parties assert that lower-order federal and state statutes violate the higher-order U.S. Constitution, parties also argue that lower-order federal administrative rules violate higher-order federal statutes. To evaluate the latter claim, federal courts rely on Chevron deference, a judicially created test for determining whether an administrative rule violates a statute. As many readers likely already know, jurists and scholars have argued that the test

126. Marbury v. Madison, 5 U.S. (1 Cranch) 137, 177, 178 (1803).

127. Id. at 178 .

128. Id. at 180 .

129. Id. at $177-78$.

130. Id. at 180 . 
violates the separation of powers. By reviewing Cheuron deference and the separation-of-powers argument against it, as well as by showing how Chevron subverts the Supremacy Clause, I provide an appetizer-by-analogy before serving up this Article's entrée.

\section{A. Challenging Administrative Rules}

The modern federal executive branch contains many administrative agencies. By statute, Congress has delegated certain legislative power to agencies to adopt administrative rules (also known as regulations) that, like statutes, establish generally applicable rules of conduct. ${ }^{131}$ Agencies then enforce those rules. In most cases (albeit sometimes after a lengthy administrative review process), a party adversely affected by an agency's enforcement (or threatened enforcement) of a rule can seek review of the agency's action in federal court. ${ }^{132}$

As part of that judicial review of administrative action, parties often challenge the administrative rule itself. These challenges implicate the hierarchy of laws. Although LOTUS-MIP rank "supreme" under the Supremacy Clause, administrative rules are not statutes at all, much less LOTUS-MIP. They rank lower than LOTUS-MIP. A party challenging an administrative rule thus essentially argues: both the rule and a statute govern the conduct at issue, but those two sources of law conflict; based on the judicial duty to privilege higher-order law over contrary lower-order law and the Supremacy Clause's elevation of LOTUS-MIP above contrary administrative rules, the statute governs and the administrative rule-at least as applied to the conduct at issue-is unenforceable or void.

As explained at length above, the judicial power entails exercising judgment to apply law in particular cases; interpreting the meaning of law to ascertain its best, fairest, and correct meaning; and when multiple sources of applicable law conflict, privileging higher-order law over lower-

131. Under current Supreme Court precedent, Congress has authority to delegate its constitutionally vested legislative power to the executive branch, so long as it "lay[s] down by legislative act an intelligible principle to which the person or body authorized to [exercise the delegated authority] is directed to conform." Mistretta v. United States, 488 U.S. 361, 372 (1989) (second alteration in original) (quoting J. W. Hampton, Jr., \& Co. v. United States, 276 U.S. 394, 409 (1928))). A majority of sitting Justices have questioned the continued veracity of this broad authority to delegate power. See Paul v. United States, 140 S. Ct. 342 (2019) (mem.) (Kavanaugh, J., statement respecting the denial of certiorari); Gundy v. United States, 139 S. Ct. 2116, 2131-42 (2019) (Gorsuch, J., dissenting, joined by Roberts, C.J., and Thomas, J.); id. at 2130-31 (Alito, J., concurring in the judgment). Moreover, the Supreme Court's delegation doctrine wholly ignores how the powers vested in each branch under the Constitution are themselves delegations from the People. See infra note 163. See generally Hamburger, Unlawful, supra note 56, at 377-402.

132. The most common vehicle is the Administrative Procedure Act. See 5 U.S.C. $\$ \S 701-06(2018)$. 
order law. ${ }^{133}$ To that end, when a party claims that a lower-order law (administrative rule) conflicts with a higher-order law (federal statute), a court must determine whether a conflict actually exists. To determine whether a conflict exists, in turn, the court must logically first know what both sources of law mean; it is not possible to say that laws conflict if their respective meanings are not known. The first task in exercising judicial power, then, includes ascertaining the best, fairest, and correct meaning of two sources. Only then will the court be able to evaluate them for actual conflict; and if conflict exists, the court will apply the higher-order law and disregard the lower-order law. This entire process of reasoning is the essence of judicial power.

Building on Figure A from earlier, the judicial power envisions determining a line of correctness for both the statute and the administrative rule. If the lines match, so to speak, there is no conflict; the court applies the administrative rule (Figure B).

FIGURE B

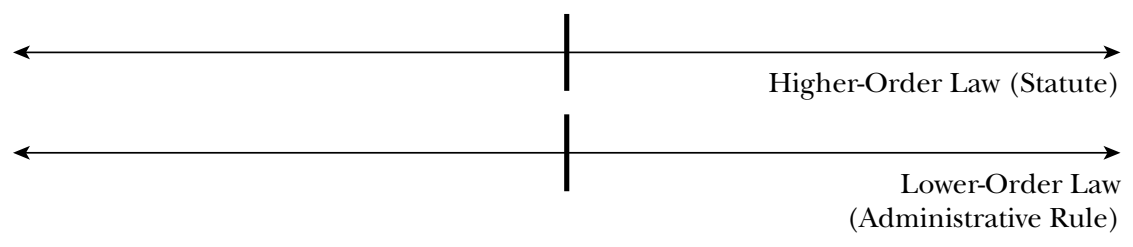

But if the lines deviate, then the judicial power and duty instruct that the statute prevails (Figure $\mathrm{C}$ ).

Figure C

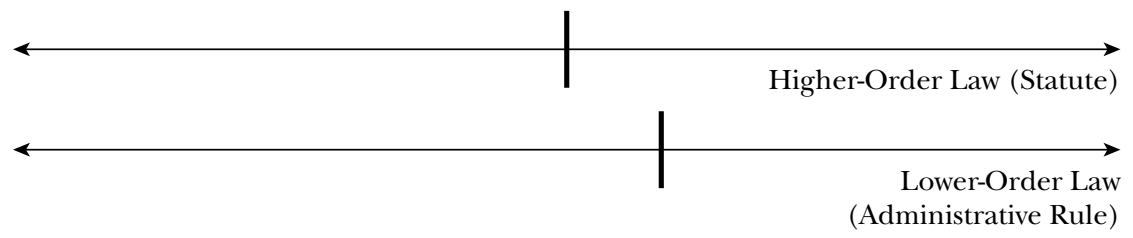

This is indeed what happens in many challenges to administrative rules when the applicable statute is unambiguous. The court interprets the rule, it interprets the statute, and if the two conflict, it enforces the statute and holds the administrative rule unenforceable. But that is not what happens when a statute is ambiguous-at least not since the Su-

133. See supra notes 12, 93-95 and accompanying text; see also Marbury, 5 U.S. ( 1 Cranch) at 177 ("It is emphatically the province and duty of the judicial department to say what the law is. Those who apply the rule to particular cases, must of necessity expound and interpret that rule. If two laws conflict with each other, the Courts must decide on the operation of each.”). 
preme Court's decision in Chevron U.S.A., Inc. v. Natural Resources Defense Council, Inc. ${ }^{134}$

\section{B. Chevron and the Zone of Deference}

Chevron featured a challenge to an Environmental Protection Agency (EPA) administrative rule about air-pollution control measures. The Clean Air Act, a federal statute, regulates certain conduct regarding "sources" of pollution but does not define "source." In an administrative rule, the EPA adopted its own definition of "source." Challengers asserted that the administrative rule was inconsistent with the Act. Writing for a unanimous Supreme Court, Justice John Paul Stevens announced a nowfamiliar framework for evaluating challenges to administrative rules. ${ }^{135}$

In such a challenge, Cheoron announced, a court first asks "whether Congress has directly spoken to the precise question at issue." 136 "If the intent of Congress is clear, that is the end of the matter; for the court, as well as the agency, must give effect to the unambiguously expressed intent of Congress." 137 This framework is so far consistent with how one would anticipate a court to exercise the judicial power. But Chevron then added a twist:

134. Chevron, U.S.A., Inc. v. Nat. Res. Def. Council, Inc., 467 U.S. 837 (1984). For a discussion of the history of judicial review of administrative action, see Aditya Bamzai, The Origins of Judicial Deference to Executive Interpretation, 126 Yale L.J. 908, 927-29 (2017); Scalia, supra note 95, at 512-13. Some have argued that Chevron deference was a small step from decades- and centuries-old standards for reviewing executive action. See Bamzai, supra, at 927-29. Others, most notably Justice Thomas, have argued that Chevron's transfer of power drastically departed from past practice. See Baldwin v. United States, 140 S. Ct. 690, 692-94 (2020) (mem.) (Thomas, J., dissenting from denial of certiorari). Undertaking a painstaking review of nineteenth and early twentieth century cases, Bamzai has concluded that Chevron signifies a pronounced departure from the traditional judicial role:

I have traced the origins and development of the doctrine of judicial deference to executive interpretation. The fundamental payoff of the historical analysis has been the insight that judicial deference-as an interpretive theory practiced from the mid-twentieth century onwards and especially after the Court's opinion in Chevron-is an innovation. Although some forms of "respect" for executive constructions did exist in traditional interpretive methodology, the modern doctrine finds no true historical antecedent in the nineteenth century, neither in the cases applying the traditional canons of construction on which Chevron relied, nor in the cases applying the standard for obtaining a writ of mandamus.

Bamzai, supra, at 1000. "But the proposition that Chevron has a basis in traditional interpretive methodology, the views of the Framers of the United States Constitution, or section 706 of the Administrative Procedure Act should be abandonedthat proposition is a fiction." Id. at 1001.

135. The Chevron-deference framework applies to all agency interpretations of statutes with the force of law. See, e.g., Christensen v. Harris County, 529 U.S. 576, 587 (2000).

136. Chevron, 467 U.S. at 842.

137. Id. at 842-43. 
[If] Congress has not directly addressed the precise question at issue, the court does not simply impose its own construction on the statute, as would be necessary in the absence of an administrative interpretation. Rather, if the statute is silent or ambiguous with respect to the specific issue, the question for the court is whether the agency's answer is based on a permissible construction of the statute. ${ }^{138}$

In short, Chevron "announced the principle that the courts will accept an agency's reasonable interpretation of the ambiguous terms of a statute that the agency administers." 139

Under Chevron, instead of exercising independent judgment in the interpretation of the law to ascertain the best, fairest, and "right answer, no matter how closely balanced the question may seem to be," 140 courts exercise merely a portion of the judicial power. They exercise judicial power only up to the point at which all remaining possible interpretations of a statute are "permissible"141 or "reasonable." 142 After that conceptual juncture, the executive branch exercises judicial power up to the point of conclusively determining meaning.

Of course, just because multiple permissible interpretations exist does not mean they are equally valid. ${ }^{143}$ Yet a court applying Cheuron deference accepts an agency's interpretation of a statute as controlling, even if it is not, in the court's view, the best, fairest, or correct interpretation. The court "does not simply impose its own construction on the statute," ${ }^{144}$ nor does it adopt "even the reading [it] would have reached if the question initially had arisen in a judicial proceeding." 145

Returning again to graphical renderings, a court interpreting a LOTUS-MIP (higher-order law) under Chevron does not establish a line of correctness delineating the best, fairest, and correct interpretation of that law. It instead sets a zone of deference within which all permissible interpretations reside-including among others the best, fairest, and correct interpretation. And then the court stops. This does not mean, however, that the statutory line of correctness ceases to exist or that the judicial power stops being exercised just because it stops being exercised by a court. As Figure D shows, the court exercises judicial power from the outset up to the zone of deference. Picking things up from there, the executive branch administrative agency then exercises the remnant judicial power

138. Id. at 843 .

139. Scalia, supra note 95 , at 511 .

140. Id. at 520 .

141. Chevron, 467 U.S. at 843-44.

142. E.g., Encino Motorcars, LLC v. Navarro, 136 S. Ct. 2117, 2124 (2016); Entergy Corp. v. Riverkeeper, Inc., 556 U.S. 208, 218 (2009); United States v. Mead Corp., 533 U.S. 218, 219 (2001).

143. Scalia, supra note 95 , at 520 .

144. Id. at 512 (quoting Chevron, 467 U.S. at 843).

145. Chevron, 467 U.S. at 843 n.11. 
from the boundary of the zone of deference up to its own substitute line of correctness, thereby conclusively saying what the law is.

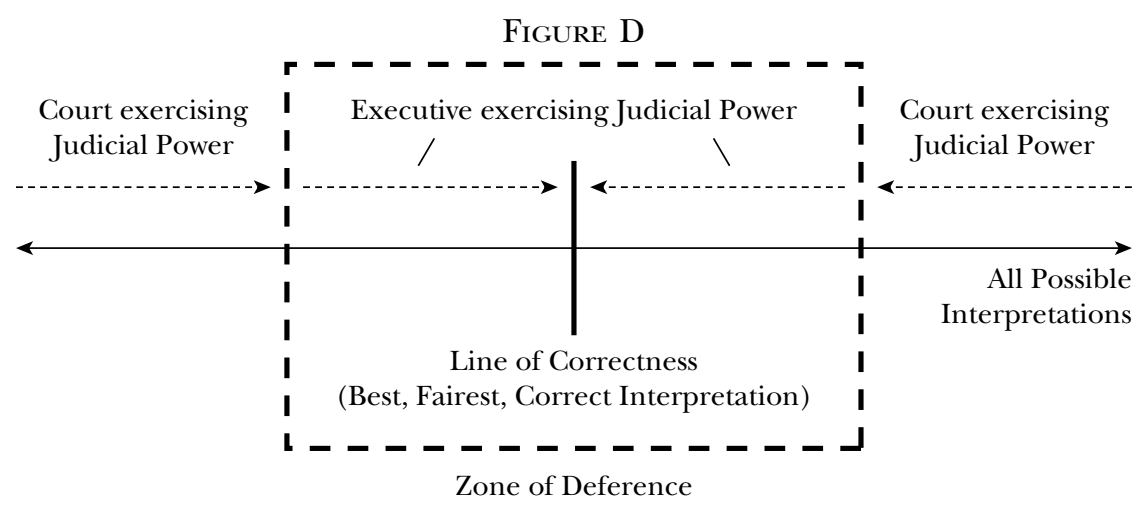

So, instead of evaluating whether the lower-order administrative rule is consistent with or contrary to the best, fairest, and correct interpretation of the higher-order LOTUS-MIP (by comparing their respective lines of correctness, as shown above in Figures B and C), the court only goes so far as to determine whether the administrative rule lies within the statute's zone of deference. Chevron deference then equates the statutory line of correctness with whatever the agency adopted in its rulemaking processso long as the agency did so within the zone of deference (see Figure E). Because the administrative agency both writes the administrative rule and dictates the substitute line of correctness, the administrative rule-once within the zone of deference-will always be upheld and applied.

Figure E

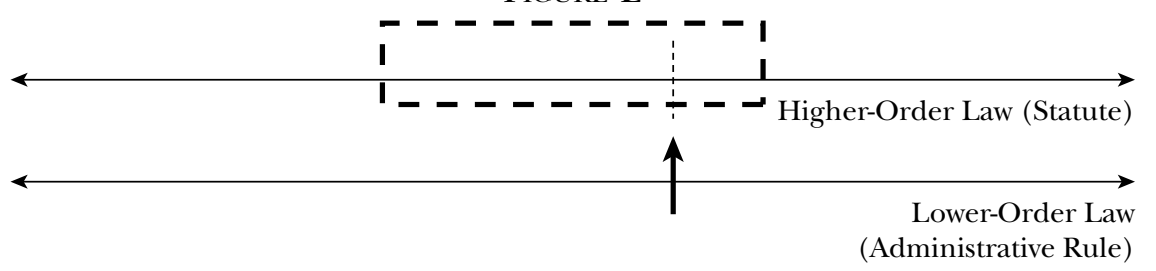

To illustrate by example, consider City of Arlington v. Federal Communications Commission. ${ }^{146}$ The Telecommunications Act of 1996 requires state and local governments to act on wireless siting applications "within a reasonable period of time after the request is duly filed." 147 The Federal Communications Commission (FCC), the agency charged with administering the Act, determined that "reasonable period of time" means presumptively (but rebuttably) 90 days to process a collocation application and 150

146. 569 U.S. 290 (2013).

147. 47 U.S.C. $§ 332$ (c) (7) (B) (ii) (2018). 
days to process all other applications. Relying on Chevron, the Fifth Circuit-and ultimately the Supreme Court-concluded that this interpretation was reasonable, and hence the FCC's administrative rule controlled. But neither court ever said that the FCC's rule was consistent with the best, fairest, and correct meaning of the Telecommunications Act. In the absence of Chevron, a court might reach the same conclusion after fully exercising the judicial power and ascertaining statutory meaning-or it might, for instance, determine that "reasonable period" is a case-specific inquiry dependent on the totality of the circumstances. The point is that the Court did not conclusively determine statutory meaning; the FCC did. And because the Court reached the point of concluding that the FCC's interpretation was within the zone of deference-permissible and reasonable, but not necessarily the best, fairest, or correct interpretation ${ }^{148}$-it stopped exercising judicial power. The FCC then effectively exercised judicial power from the border of the zone of deference up to the point of adopting the 90/150-day rule, which the Court then accepted and applied as a substitute line of correctness.

\section{Constitutional Problems with Chevron Deference}

Cheuron deference has been the object of many scholars' and jurists' ire. Criticisms of Chevron have come from all corners, some grounded in policy, some in statutory law, and some in the Constitution. ${ }^{149}$ Here, I

148. "Best and fairest" is borrowed from Justice Gorsuch's concurring opinion in Kisor $v$. Wilkie, a case about the related Auer deference doctrine, under which courts in certain circumstances defer to agencies' interpretations of their own regulations. Kisor v. Wilkie, 139 S. Ct. 2400, 2425 (2019) (Gorsuch, J., concurring). Although Auer bears resemblance to Chevron, and although the criticisms launched against both doctrines are similar, courts still treat them differently. Concurring in part in Kisor, Chief Justice John Roberts took pains to announce: "Issues surrounding judicial deference to agency interpretations of their own regulations are distinct from those raised in connection with judicial deference to agency interpretations of statutes enacted by Congress. I do not regard the Court's decision today to touch upon the latter question." Id. at 2425 (Roberts, C.J., concurring in part) (citation omitted).

149. For example, some have argued that Chevron deference contravenes the Administrative Procedure Act. See, e.g., Baldwin v. United States, 140 S. Ct. 690, 692 (2020) (mem.) (Thomas, J., dissenting from denial of certiorari); GutierrezBrizuela v. Lynch, 834 F.3d 1142, 1153 (10th Cir. 2016) (Gorsuch, J., concurring); The Chevron Doctrine: Constitutional and Statutory Questions in Judicial Deference to Agencies: Hearing Before the Subcomm. on Reg. Reform, Commercial \& Antitrust Law of H. Comm. on Judiciary, 115th Cong. (2016) (statement of John F. Duffy, Professor of Law, Univ. of Va.), http:/ / docs.house.gov/meetings/JU/JU05/ 20160315/104665/HHRG-114-JU05-Wstate-DuffyJ-20160315.pdf [https:// perma.cc/Q6ZG-8PA3]; Bamzai, supra note 134, at 985-94. Some have criticized Chevron on administrability and policy grounds. See, e.g., Jack M. Beermann, Chevron at the Roberts Court: Still Failing After All These Years, 83 Fordham L. Rev. 731 (2014); Jack M. Beermann, End the Failed Chevron Experiment Now: How Chevron Has Failed and Why It Can and Should Be Overruled, 42 Conn. L. Rev. 779 (2010). Some have raised due-process concerns. See, e.g., Gutierrez-Brizuela, 834 F.3d at 1152 (Gorsuch, J., concurring) ("Transferring the job of saying what the law is from the judiciary to the executive unsurprisingly invites the very sort of due-process (fair 
focus on one of those constitutional critiques: the tension between Chevron and the structural separation of powers. In so doing, I also comment on the interplay between Chewron and the Supremacy Clause.

As explained above, the judicial power entails "say[ing] what the law is" 150 by ascertaining the best, fairest, and correct ${ }^{151}$ interpretation of law and applying that law to adjudicate particular disputes. "[A]s originally understood," the judicial power requires courts to exercise "independent judgment in interpreting and expounding upon the laws," "including ambiguous ones administered by an agency." 152 Under Chevron, however, a court exercises only a part of the judicial power. Judges still decide whether a statute is ambiguous and whether the agency's view is permissible. Yet "where in all this does a court interpret the law and say what it is?"153

The remnant judicial power-that portion beyond merely evaluating the range of permissible or reasonable interpretations (setting the zone of deference) up to the point of fully ascertaining a statute's meaning in a particular case-still exists, of course. But under Chevron, courts do not exercise it, prompting then-Judge Gorsuch to call the doctrine "no less than a judge-made doctrine for the abdication of the judicial duty." 154

In applying Chevron deference, not only do federal courts fail to exercise their full judicial power and duty, they abdicate and transfer (or delegate) part of that power to the executive branch. Rather than interpreting higher-order LOTUS-MIP up to the line of correctness and refusing to apply contrary lower-order administrative rules, courts under Chewron "must allow an executive agency to resolve the meaning of any ambiguous statutory provision." ${ }^{155}$ Chewron deference forces judges to "lay aside" the full scope of their judicial power and "declare affirmatively" that "the law is what the agency says it is," 156 often simultaneously "abandon[ing] what

notice) and equal-protection concerns the framers knew would arise if the political branches intruded on judicial functions."); Christopher J. Walker, Attacking Auer and Chevron Deference: A Literature Review, 16 Geo. J.L. \& Pub. Pol'y 103, 112 (2018) (citing Philip Hamburger, Chevron Bias, 84 Geo. Wash. L. Rev. 1187, 1189 (2016)) (relying on Philip Hamburger's research to argue that "Chevron deference imbues the federal judiciary with institutional bias in favor of the most powerful parties (the federal bureaucracy), which violates parties' due process rights when their life, liberty, or property is at issue").

150. Marbury v. Madison, 5 U.S. (1 Cranch) 137, 177 (1803); see also supra Section II.B.

151. See supra notes $12,93-95$ and accompanying text.

152. Michigan v. EPA, 135 S. Ct. 2699, 2712 (2015) (Thomas, J., concurring) (quoting Perez v. Mortg. Bankers Ass'n, 135 S. Ct. 1199, 1217-19 (2015) (Thomas, J., concurring in judgment)).

153. Gutierrez-Brizuela, 834 F.3d at 1152 (Gorsuch, J., concurring).

154. Id.

155. Id.

156. Kisor v. Wilkie, 139 S. Ct. 2400, 2440 (2019) (Gorsuch, J., concurring). 
they believe is "the best reading of an ambiguous statute." 157 In short, Chevron "wrests from Courts the ultimate interpretative authority to 'say what the law is,' and hands" over part of that judicial power and duty to the executive. ${ }^{158}$

This is constitutionally problematic, because Article III's Vesting Clause vests "every single drop" of the judicial power in the courts-not elsewhere. ${ }^{159}$ " $[\mathrm{N}]$ ever," the Supreme Court has warned, "should the "judicial power . . . be shared with [the] Executive Branch." "160 As Justice Story expanded, "in cases where [a court's] own judgment shall differ from that of other high functionaries," the court "is not at liberty to surrender, or to waive" the judicial power or its concomitant duty. ${ }^{161}$ But Chevron deference violates these principles. Unsurprisingly, several current and former Supreme Court jurists have questioned Chevron's validity or outright called for its demise. ${ }^{162}$ So too have many commentators rec-

157. Michigan, 135 S. Ct. at 2712 (Thomas, J., concurring) (quoting Nat'l Cable \& Telecomm'ns Ass'n v. Brand X Internet Servs., 545 U.S. 967, 983 (2005)). Christopher Walker has argued that Chevron deference presents separation-of-powers concerns from yet another angle-by siphoning the legislature's power. "The deference required by Chevron not only erodes the role of the judiciary," "it also diminishes the role of Congress." Walker, supra note 149, at 112 (quoting Egan v. Del. River Port Auth., 851 F.3d 263, 279 (3d Cir. 2017) (Jordan, J., concurring in the judgment)). "In particular, Article I vests Congress with 'All legislative Powers,' yet Chevron deference encourages members of Congress to delegate broad lawmaking power to federal agencies. In doing so, Congress further frustrates the values of the nondelegation doctrine." Id.; see also Michigan, 135 S. Ct. at 2713 (Thomas, J., concurring); Manning, Constitutional Structure, supra note 60, at 625. Finally, Walker has also theorized about potential Article II concerns. Walker, supra note 149 , at $113-15$.

158. Michigan, 135 S. Ct. at 2712 (2015) (Thomas, J., concurring) (citation omitted) (quoting Marbury v. Madison, 5. U.S. (1 Cranch) 137, 177 (1803)).

159. Ortiz v. United States, 138 S. Ct. 2165, 2190 (2018) (Alito, J., dissenting); see also Michigan, 135 S. Ct. at 2712 (Thomas, J., concurring) ("Such a transfer is in tension with Article III's Vesting Clause, which vests the judicial power exclusively in Article III courts, not administrative agencies."). The Constitution provides "no exception" to the rule that "the judicial power of the United States may be vested only in tribunals whose judges have life tenure and salary protection." Ortiz, $138 \mathrm{~S}$. Ct. at 2190; accord Oil States Energy Servs., LLC v. Greene’s Energy Grp., LLC, 138 S. Ct. 1365, 1372-73 (2018); Stern v. Marshall, 564 U.S. 462, 503 (2011); Martin v. Hunter's Lessee, 1 Wheat. 304, 330-31 (1816).

160. Kisor, 139 S. Ct. at 2437 (Gorsuch, J., concurring) (second and third alteration in the original) (quoting Miller v. Johnson, 515 U.S. 900, 922 (1995)).

161. United States v. Dickson, 40 U.S. (15 Pet.) 141, 162 (1841) (Story, J.).

162. See Baldwin v. United States, 140 S. Ct. 690, 691-92 (2020) (mem.) (Thomas, J., dissenting from denial of certiorari); BNSF Ry. Co. v. Loos, 139 S. Ct. 893, 908-09 (2019) (Gorsuch, J., dissenting) (referring to "the mounting criticism of Chevron deference," musing how a party seemingly entitled to invoke the doctrine in its favor barely mentioned it and even hated doing so, and concluding that "this is all to the good"); Pereira v. Sessions, 138 S. Ct. 2105, 2121 (2018) (Kennedy, J., concurring) (Because "[t]he proper rules for interpreting statutes and determining agency jurisdiction and substantive agency powers should accord with constitutional separation-of-powers principles and the function and province of the Judiciary," "it seems necessary and appropriate to reconsider, in an appropriate case, the premises that underlie Chevron and how courts have implemented 
ognized the tension between Cheoron deference and constitutional structure. ${ }^{163}$ As John Manning has put it, "If law interpretation "is the proper

that decision.”); Michigan, 135 S. Ct. 2699 (2015) (Thomas, J., concurring); City of Arlington v. FCC, 569 U.S. 290, 315-16 (2013) (Roberts, C.J., dissenting) (quoting Marbury v. Madison, 5 U.S. (1 Cranch) 137, 177 (1803)) (observing how " $[\mathrm{t}] \mathrm{he}$ rise of the modern administrative state has not changed" the fact that it is "emphatically the province and duty of the Judicial Department to say what the law is," and admonishing that the "danger posed by the growing power of the administrative state cannot be dismissed"); Gutierrez-Brizuela v. Lynch, 834 F.3d 1142 (10th Cir. 2016) (Gorsuch, J., concurring); Amanda Riley, Would Kavanaugh Limit the Chevron Doctrine? E\&E News (July 10, 2018), https://www.eenews.net/stories/ 1060088675 [https://perma.cc/PL39-WQHV] (regarding Kavanaugh).

Although Justice Scalia's judicial and scholarly writings seem to waffle between strident support for deference and steadfast rejection of the same, there is little doubt that Chevron made him at least uncomfortable. Shortly after Chevron was decided, Scalia observed that

[i] t is not immediately apparent why a court should ever accept the judgment of an executive agency on a question of law. Indeed, on its face the suggestion seems quite incompatible with Marshall's aphorism that " $[\mathrm{i}] \mathrm{t}$ is emphatically the province and duty of the judicial department to say what the law is." Surely the law, that immutable product of Congress, is what it is, and its content-ultimately to be decided by the courts-cannot be altered or affected by what the Executive thinks about it.

Scalia, supra note 95, at 513 (second alteration in original) (footnote omitted) (quoting Marbury, 5 U.S. at 177). Although deferring to the views of the government or its officers might be a matter of respect, "to say that those views, if at least reasonable, will ever be binding — that is, seemingly, a striking abdication of judicial responsibility." Id. at 514 .

Separately, perhaps recognizing the constitutional problems with Chevron, "[t] he Supreme Court has expressly instructed [courts] not to apply Chevron deference when an agency seeks to interpret a criminal statute." Gutierrez-Brizuela, 834 F.3d at 1155 (10th Cir. 2016) (Gorsuch, J., concurring) (citing Abramski v. United States, 134 S. Ct. 2259, 2274 (2014)). As stated by then-Judge Gorsuch, deferring to an agency's interpretation of a criminal statute "would violate the Constitution by forcing the judiciary to abdicate the job of saying what the law is and preventing courts from exercising independent judgment in the interpretation of statutes." $I d$.

163. Manning, Constitutional Structure, supra note 60, at 621. Not only does abdication and transfer of power-from one branch to another-violate the structural separation of powers, it also raises other constitutional concerns. The legislative, executive, and judicial powers vested in the respective federal branches did not emerge from the ether; they were initially delegated from the People. See Hamburger, Unlawful, supra note 56, at 377, 380 ("By means of the Constitution, the people delegate power to the government. In particular, they delegate a specialized power to each branch of government .... . Delegation was the principle by which the people established their republic and kept their power superior to that of their government . . . ."); see also Gundy v. United States, 139 S. Ct. 2116, 2133-34 (2019) (Gorsuch, J., dissenting) (quoting John Locke, The Second Treatise of Civil Government and a Letter Concerning Toleration $\$ 141$, at 71 (J.W. Gough ed., Basil Blackwell Oxford 1947) (1689)) (describing problems accompanying delegation of legislative power to executive officials). Being delegated once already, the branches cannot further subdelegate that power by transferring it elsewhere. See Hamburger, Unlawful, supra note 56, at 386 ("[T] he Constitution . . . expressly bars the subdelegation of [vested] powers."); see also id. at 377 ("[W] hen [one branch] purports to give its [vested] power to [a different branch], the question is not whether the principal can delegate the 
and peculiar province of the courts,' why should a court ever decide a case or controversy based on a reading of the law with which it disagrees?" 164 In Marbury's terms, Chevron limits a court's exercise of judicial power, modifying it from saying what the law is to saying what the law could permissibly be. ${ }^{165}$

Cheuron's transfer of judicial power and corresponding separation-ofpowers violation is not harmless. ${ }^{166}$ Article III judges exercising judicial

power, but whether the agent can subdelegate it."); $i d$. at 380-85 (tracing history of declaring governmental subdelegations unlawful, and concluding that "far from being a mere doctrine or a mere nicety of political theory, the effect of delegation in precluding any subdelegation was a foundation of political freedom"). See generally Robert G. Natelson, The Constitution and the Public Trust, 52 Buff. L. Rev. 1077 (2004). Well-worn principles of agency law are instructive: a principal may delegate authority to an agent, but the agent may not further subdelegate absent express permission to do so from the principal. See Hamburger, Unlawful, supra note 56, at 386; accord Restatement (Second) Agency $\$ 18$ (Am. Law Inst. 1954). See generally Gary Lawson \& Guy Seidman, "A Great Power of Attorney": UnderStanding the Fiduciary Constitution (2017). Otherwise there could be an infinite chain of delegation, with each delegee further and further attenuated from the original principal. These principles apply wholeheartedly to condemn the abdication and transfer of judicial power by Article III judges and courts to nonArticle III actors. See Hamburger, Unlawful, supra note 56, at 396-98 (discussing subdeledgation of judicial power specifically); $i d$. at 398 ("In the Constitution, the people of the United States delegate judicial power to courts composed of judges, and as evident from the nomination and confirmation process, judges are appointed for their personal qualities. The judges therefore cannot transfer their office, and the courts cannot transfer their power."); $i d$. at 397 (alteration in original) (internal quotation marks omitted) (quoting Sir Leoline Jenkins, manuscript notes in interleaved copy of Richard Zouche, CASES AND Questions OF Right AND Judicature, Resolved in the Civil-Law 12ff (1652)) (Our law is that a judge cannot make a deputy ... for he is constituted upon presumption of his knowledge and integrity (qualities personal and not communicable)."). After all, if "[i]t will not be contended that Congress can delegate to the Courts, or to any other tribunals, powers which are strictly and exclusively legislative," Wayman v. Southard, 23 U.S. (10 Wheat.) 1, 42 (1825) (Marshall, J.), then how could it be contended that the federal courts can delegate their judicial power elsewhere?

Separately, Philip Hamburger has also argued that instead of "delegation" and "non-delegation," it may be more appropriate to frame issues of inter-branch authority in terms of "vesting" and "divesting." See Philip Hamburger, Delegating or Divesting?, 115 Nw. U. L. Rev. Online 88, 108-10 (2020). “[I]n the Constitution," after all, "generic nondelegation principle [became] a more specific matter of vesting." Id. at 108. The language of "vesting" "speaks more forcefully than prior antidelegation theories and does not leave its meaning to be implied from such theories." Id. Ultimately, "because the Constitution vests all legislative powers in Congress, Congress cannot vest any such powers elsewhere." Id. at 110. And "Congress cannot divest itself of the powers that the Constitution vests in it." Id.

164. Manning, Constitutional Structure, supra note 60, at 621 (footnote omitted) (quoting The Federalist No. 78, supra note 61, at 467 (Alexander Hamilton)).

165. But see, e.g., Henry Monaghan, Marbury and the Administrative State, 83 Colum. L. Rev. 1, 27-28 (1983) ("[T] he court is not abdicating its constitutional duty to 'say what the law is' by deferring to agency interpretations of law: it is simply applying the law as 'made' by the authorized law-making entity").

166. Baldwin v. United States, 140 S. Ct. 690, 691-92 (2020) (mem.) (Thomas, J., dissenting from denial of certiorari). 
power enjoy constitutional safeguards of tenure and salary protection, insulating them from politics and the threat of "human will." 167 Executive branch officers by design have no such protections; under Cheuron deference, they exercise judicial power without Article III's safeguards. "The Executive is not insulated from external threats, and it is by definition an agent of will, not judgment." 168 Even if Chevron's transfer of power and compromise of structural separation might not be "the very definition of tyranny," 169 it no doubt raises many of the general concerns that prompted the Constitution's tripartite division of powers in the first instance. ${ }^{170}$

None of this is to suggest, however, that executive interpretation might not properly and constitutionally serve as evidence of statutory meaning. ${ }^{171}$ But "respect[ing] executive interpretations" because "they embodied understandings made roughly contemporaneously with" statutory enactment differs from accepting them "because they were executive as such." ${ }^{72}$ Indeed, Chevron's separation-of-powers problem arises not from deference per se, that "mealy-mouthed word ... not necessarily meaning anything more than considering those views with attentiveness and profound respect." 173 The problem rather arises from binding deference, the core Chevron notion that a court's task ends once it concludes that the agency's interpretation is permissible and lies within the zone of deference. ${ }^{174}$

In addition, by abdicating part of its judicial power and duty, courts applying Chevron deference also subvert the legal hierarchy set forth in the Supremacy Clause. LOTUS-MIP indisputably rank higher than federal administrative rules. Yet by permitting administrative rules to pass without

167. Id.; see also Perez v. Mortg. Bankers Ass'n, 575 U.S. 92, 120 (2015) (Thomas, J., concurring in the judgment); Hamburger, LAw, supra note 104, at 507, 508.

168. Baldwin, 140 S. Ct. at 691-92 (2020) (mem.) (Thomas, J., dissenting from denial of certiorari).

169. The Federalist No. 47, supra note 61, at 298 (James Madison).

170. See supra Section II.A.

171. Cf. Michael Stokes Paulsen, The Most Dangerous Branch: Executive Power to Say What the Law Is, 83 GEO. L.J. 217, 336 n.413 (1994) ("I emphatically reject the view, which sometimes travels under the name of deference, that an interpreter (typically, a judge) should reach a conclusion different from the one produced by her best legal analysis, or should refrain from reaching any conclusion at all, because of the views of another. While an interpreter may be persuaded or influenced in the exercise of her own judgment by the views and reasoning of another, any theory that accords decision-altering weight to the views of another, contrary to the interpreter's settled conviction as to the proper interpretation of the provision at issue, is fundamentally illegitimate.").

172. Kisor v. Wilkie, 139 S. Ct. 2400, 2426 (2019) (Gorsuch, J., concurring) (third internal quotation marks omitted) (quoting Bamzai, supra note 134, at 943, 962).

173. Scalia, supra note 95 , at 514.

174. See Manning, Constitutional Structure, supra note 60, at 617; Scalia, supra note 95 , at 513-14. 
the full scrutiny required by the judicial duty-regardless of whether a proper exercise of that duty would ultimately uphold or strike down the administrative rule-courts dishonor the Supremacy Clause's text and objective. They simultaneously bastardize the elevated status of LOTUS-MIP and illegitimately raise the status of administrative rules. How far each of those deviations extends may depend on the particular case-but if the effect is to equate them, then the result is doubtless a constitutional violation.

To be sure, not everyone agrees that Cheuron deference violates the separation of powers. Some have argued that the separation of powers actually requires Chevron deference. ${ }^{175}$ When Congress leaves an ambiguity in a statute administrated by an agency, the argument goes, "the resolution of that ambiguity necessarily involves policy judgment." "76 Because "[u]nder our democratic system, policy judgments are not for the courts," a policy-making branch must interpret and liquidate those ambiguities. ${ }^{177}$ The language of Cheuron itself buttresses this argument and relies on the principle that the executive branch is more directly accountable to the electorate than the courts. ${ }^{178}$ In challenges to administrative rules centered on a policy-focused ambiguity in statutory language, the Cherron Court said, "federal judges-who have no constituency-have a duty to respect legitimate policy choices of those who do." ${ }^{779}$

In response to the argument that the separation of powers mandates or supports Chevron deference, at least two immediate counterarguments arise. First, as mentioned above, judges regularly confront ambiguous statutes. They nonetheless find a way to ascertain meaning; that is the core judicial power to declare what the law "is." 180 There is no apparent reason why this regular judicial approach to statutory interpretation must change in cases reviewing administrative rules. Judges are still capable of fully ascertaining the meaning of ambiguous statutes even when a lower-order source of law happens to exist.

Second, as Justice Scalia objected, the traditional statutory-interpretation toolkit includes making certain policy judgments-not legislative policy judgments, to be sure, but judicial judgments in the course of ascertaining statutory meaning. ${ }^{181}$ For example, "one of the most fre-

175. Scalia, supra note 95, at 514-15; see Douglas W. Kmiec, Judicial Deference to Executive Agencies and the Decline of the Nondelegation Doctrine, 2 Admin. L.J. 269, 277-78, 283, 285 (1988). Cf. Kenneth W. Starr, Judicial Review in the Post-Chevron Era, 3 YAle J. ON Reg. 283, 308, 312 (1986) (arguing that Chevron shifts policymaking responsibility from courts to democratically accountable officials in agencies).

176. Scalia, supra note 95 , at 515 .

177. Id. (1984).

178. Chevron U.S.A., Inc. v. Nat. Res. Def. Council, Inc., 467 U.S. 837, 865-66

179. Id. at 866 .

180. See supra Section II.B.

181. Scalia, supra note 95 , at 515 . 
quent justifications courts give for choosing a particular construction is that the alternative interpretation would produce 'absurd' results, or results less compatible with the reason or purpose of the statute."182 For Justice Scalia at least, this interpretive tool "unquestionably involves judicial consideration and evaluation of competing policies." 183

\section{Why the Rational Basis Test Is Unconstitutional}

In the previous Part, I discussed Chevron deference and the arguments that it violates the separation of powers and the Supremacy Clause. Whether one agrees or disagrees with them, these arguments have achieved a level of familiarity in the legal consciousness. In this Part, I show how the same constitutional provisions and principles-the separation of powers, the judicial power, and the Supremacy Clause-work together similarly to cast doubt on the rational basis test. Cheuron deference departs from the Constitution because courts applying it abdicate their power and duty to say what the law is. The rational basis test functions the same way when the law in question is the Constitution. As Chief Justice Marshall famously proclaimed, it is the "province and duty of the Judicial Department to say what the law is" - not what it rationally could be, and not what Congress or a state legislature thinks it is.

\section{A. Judicial Review of Statutes}

Both Congress and state legislatures enact generally applicable rules of conduct in the form of statutes. When parties find themselves subject to a federal or state statute, they often argue that the statute violates the U.S. Constitution's substantive provisions. ${ }^{184}$ Just like with challenges to administrative rules, these challenges to statutes implicate the hierarchy of laws.

First, consider state statutes. Under the Supremacy Clause, the U.S. Constitution and LOTUS-MIP rank "supreme," with state statutes occupying a subordinate position. A party challenging a state statute under the federal Constitution essentially argues: both the state statute and the U.S. Constitution govern the conduct at issue, but those two sources conflict; based on the judicial duty to privilege higher-order law over contrary lower-order law and the Supremacy Clause's explanation that the U.S. Constitution ranks higher than state statutes, the Constitution governs and

182. $I d$.

183. Id.

184. This Article does not address challenges to state statutes based on inconsistency with a federal statute or a state constitution. Nor does this Article address challenges based on failure to follow constitutional procedure. 
the state statute-at least as applied to the conduct at issue ${ }^{185}$-is unenforceable or void. ${ }^{186}$

Next, consider federal statutes. The Supremacy Clause declares the U.S. Constitution and LOTUS-MIP "supreme." At first blush, federal statutes and the Constitution occupy the same level of the legal hierarchy. But that is not the whole story. As discussed above, if a federal statute (law of the United States) is "made in Pursuance" of the Constitution, then, by definition, it is consistent with the Constitution-and no question of hierarchy arises. On the other hand, if a federal statute is not "made in Pursuance" of the Constitution, then it does not qualify as supreme, and it ranks lower than the Constitution. ${ }^{187}$ The Constitution, in short, prevails over contrary federal statutes. In a challenge to a federal statute, the central issue is whether the statute is consistent with-in other words, "made in Pursuance" of-the Constitution. A party challenging a federal statute under the Constitution thus essentially argues: both the federal statute and the Constitution govern the conduct at issue, but those two sources conflict; based on the judicial duty to privilege higher-order law over contrary lower-order law and the Supremacy Clause's explanation that the Constitution ranks higher than federal statutes not made in pursuance, the Constitution governs, and the contrary federal statute-at least as applied to the conduct at issue-is unenforceable or void.

Challenges to both state and federal statutes, then, similarly implicate the judicial power and the Supremacy Clause's hierarchy. Again, the judicial power entails exercising judgment to apply law to particular disputes; interpreting the meaning of law to ascertain its best, fairest, and correct meaning; and, when multiple sources of law conflict, privileging higher-

185. Jurists and academics recognize a difference between "facial challenges" and "as-applied challenges." There is ongoing debate about the meaning and appropriateness of those labels. Scott A. Keller \& Misha Tseytlin, Applying Constitutional Decision Rules Versus Invalidating Statutes in Toto, 98 VA. L. REv. 301, 307-17 (2012); Nicholas Quinn Rosenkranz, The Objects of the Constitution, 63 Stan. L. Rev. 1005 (2011); Nicholas Quinn Rosenkranz, The Subjects of the Constitution, 62 STAN. L. Rev. 1209 (2010); see also Richard H. Fallon, Jr., As-Applied and Facial Challenges and Third-Party Standing, 113 Harv. L. Rev. 1321 (2000); Henry P. Monaghan, Overbreadth, 1981 Sup. CT. REv. 1, 3, 8-12 (1981). For the purposes of this Article, any distinction is irrelevant: courts apply the rational basis test to both types of challenges.

186. For this Article, it is unnecessary to dwell on the precise remedy appropriate when a lower-order law conflicts with a higher-order law. Although it is commonly understood that courts can "strike down" statutes, that characterization of judicial power has been questioned. See generally, e.g., Seila Law LLC v. Consumer Fin. Prot. Bureau, 140 S. Ct. 2183, 2219-20 (2020) (Thomas, J., concurring in part and dissenting in part); Jonathan F. Mitchell, The Writ-Of-Erasure Fallacy, 104 VA. L. Rev. 933 (2018).

187. See supra Section II.C. I stress again that the Supremacy Clause does not merely establish primacy of federal law over state law. It also establishes a hierarchy among different sources of federal law. 
order law over lower-order law. ${ }^{188}$ To that end, when a party claims that a conflict exists between a lower-order law (state or federal statute) and a higher-order law (U.S. Constitution), a court must determine whether a conflict actually exists. To determine whether a conflict exists, the court logically must first know what both sources of law mean. It is not possible to say that laws conflict if their respective meanings are not known. (This is analogous to challenges to administrative rules.) The first task in exercising judicial power, then, includes ascertaining the best, fairest, and correct meaning of two sources. Only then will the court be able to evaluate them for actual conflict; and if conflict exists, the court will apply the higher-order law and disregard the lower-order law.

Again building on the graphics used throughout this Article, the judicial power envisions determining a line of correctness for both the Constitution and the statute under review. If the lines match, then no conflict arises. (Figure F; compare to Figure B in the Chevron deference analogy, above.)

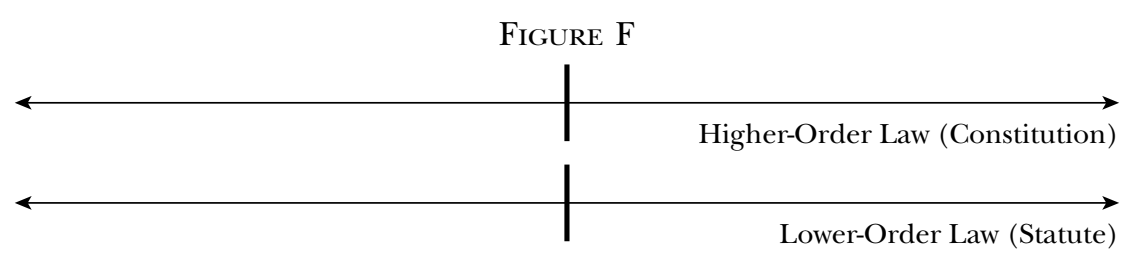

But if the lines of correctness deviate, then the judicial power and duty instruct that the Constitution prevails. (Figure G; compare with Figure $\mathrm{C}$ in the Cheuron deference analogy, above.)

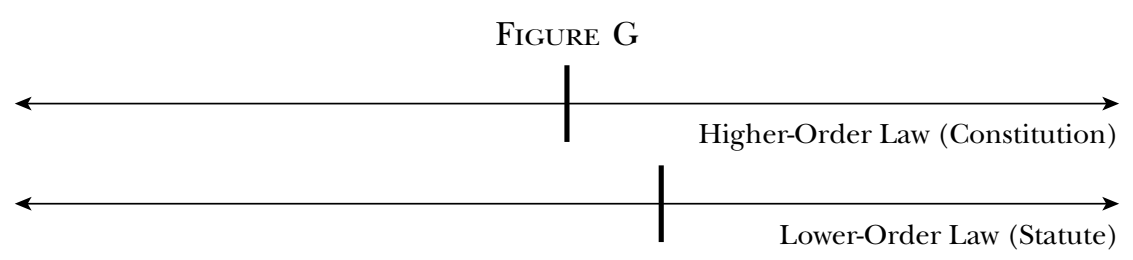

This process may indeed be what happens in certain challenges to statutes. It does not, however, take place when courts apply the rational basis test.

\section{B. Rational Basis and the Zone of Deference}

I outlined the contours of the rational basis test above in Part I. In Part III, I showed how Chevron deference manipulates and shifts the judicial power and duty when a lower-order law (administrative rule) allegedly

188. See supra notes 12, 93-95 and accompanying text; see also Marbury v. Madison, 5 U.S. (1 Cranch) 137, 177 (1803). 
conflicts with a higher-order law (LOTUS-MIP). Instead of exercising independent judgment in the interpretation of the law to ascertain the best, fairest, "right answer, no matter how closely balanced the question may seem to be," 189 courts applying Cheuron deference exercise only a portion of the judicial power.

Something very similar happens under the rational basis test. Just like how Chevron deference offers a framework for interpreting statutes, the rational basis test offers a framework for interpreting the Constitution. Courts apply the test to review whether certain lower-order laws (state statutes and federal statutes allegedly not made in pursuance) conflict with higher-order law (U.S. Constitution). And just like under Chevron, a court applying the rational basis test exercises only a portion of the judicial power.

Instead of establishing a line of correctness for both the lower-order law (state or federal statute) and the higher-order law (U.S. Constitution), the court sets a zone of deference for the higher-order law (U.S. Constitution). Within that zone of deference resides the best, fairest, and correct interpretation of the constitutional provision at issue, as well as all permissible interpretations: in the words of the rational basis test, those interpretations supporting enactments rationally related to a legitimate government purpose. But just because multiple statutes exist that are rationally related to a legitimate government purpose does not mean that they are equally valid interpretations of the constitutional provision at issue. ${ }^{190}$ Likewise, this does not mean that the constitutional line of correctness ceases to exist or that the judicial power stops being exercised just because it stops being exercised by a court. As Figure H shows (compare to Figure D in the Chevron analogy, above), the court exercises judicial power from the outset up to the zone of deference. After that point, Congress or the state legislature (as the case may be) then exercises the remnant judicial power from the zone's boundary up to that legislature's substitute line of correctness, thereby conclusively saying what the law is. In other words, especially when "'ordinary commercial transactions' are at issue," the Supreme Court has "made clear" that the rational basis test restricts its exercise of judicial power to just up to the zone of deference, beyond which a court must "defer[ ] to reasonable underlying legislative judgments." 191

189. Scalia, supra note 95 , at 520 .

190. Id.

191. Armour v. City of Indianapolis, 566 U.S. 673, 680 (2012) (quoting United States v. Carolene Prods. Co., 304 U.S. 144, 152 (1938)). 


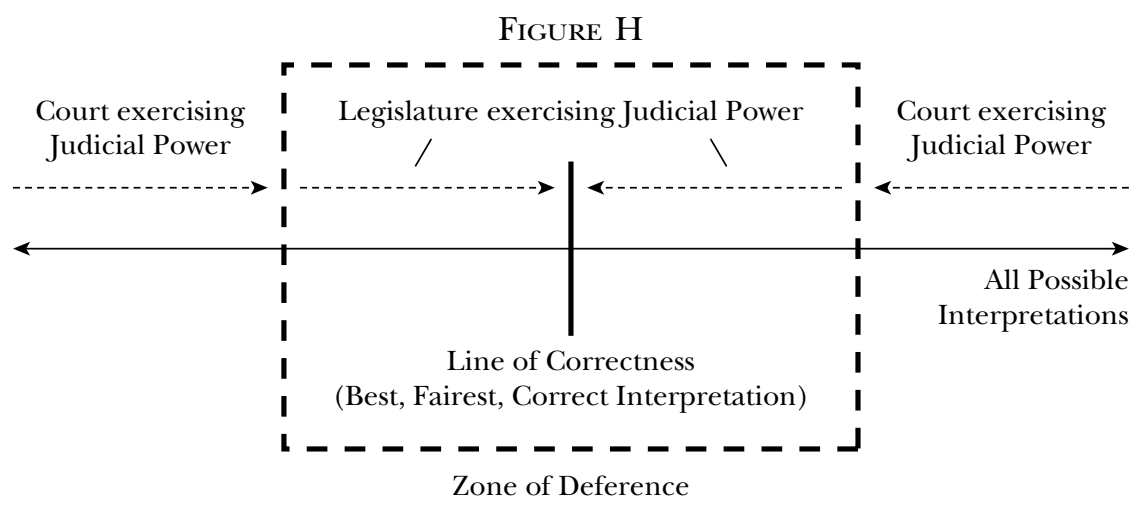

In other words, a court applying the rational basis test, analogously to a court applying Chevron deference, does not evaluate whether the lowerorder state or federal statute is consistent with or contrary to the best, fairest, and correct interpretation of the higher-order Constitution (by comparing their respective lines of correctness, as shown above in Figures F and G). It instead only goes so far as to determine whether the statute lies within the zone of deference of the constitutional provision at issue. Analogously to a court applying Chevron deference, a court applying the rational basis test accepts Congress's or the state legislature's interpretation of the constitutional provision as controlling, even if it is not, in the court's view, the best, fairest, or correct interpretation. The rational basis test, analogously to Chevron deference, equates the constitutional line of correctness with whatever the legislature enacted in the legislative process-so long as the legislature did so within the zone of deference. (Figure I; compare to Figure E in the Chevron analogy, above.) Because the legislature both writes the statute and dictates the substitute line of correctness, the statute-once within the zone of deference-will always be upheld and applied.

Figure I

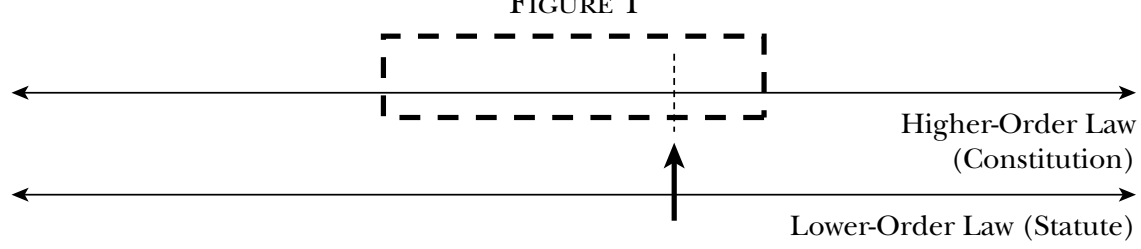

C. Constitutional Problems with Rational Basis Review of Federal Statutes

Article III vests the judicial power in courts, empowering them to "say what the law is." 192 At the risk of repeating myself one too many times, this means applying law in particular disputes; interpreting that law; and

192. Marbury v. Madison, 5 U.S. (1 Cranch) 137, 177 (1803). 
doing so within a legal hierarchy implicating a duty to privilege higherorder law over contrary lower-order law. ${ }^{193}$ Within the context of a particular dispute, the judicial power envisions courts ascertaining the best, fairest, and correct ${ }^{194}$ interpretation of a law, no matter its level in the hierarchy, even if it is ambiguous or vague. Under the rational basis test, however, courts exercise only a small part of the judicial power. Courts still decide whether a federal or state statute rationally relates to a legitimate government interest; they set the boundaries of the zone of deference. Yet, just like with Chevron deference, "where in all this does a court interpret the law"-particularly the Constitution- "and say what it is?" 195

The remnant judicial power-that portion within the zone of deference up to the point of conclusively determining a constitutional provision's meaning in a particular case-still exists. But when applying the rational basis test, courts do not exercise that remnant power. Because the judicial power and duty to say what the law is applies with equal force to the Constitution as it does to statutes, the rational basis test parallels Chevron deference as "no less than a judge-made doctrine for the abdication of the judicial duty." 196 As James McGoldrick has similarly observed, the rational basis test "has very little to do with rationality and everything to do with judicial abdication." 197 Or, to put the quandary in Marbury's terms, the rational basis test limits a court's exercise of judicial power, modifying it from saying what the law is to saying what the law rationally or conceivably could be. Rather than interpreting the constitutional provision at issue up to the line of correctness and refusing to apply contrary lower-order statutes not "made in pursuance," courts using the rational basis test, analogously to courts applying Cheuron deference, "render[ ] the precise coordinates of the resulting legislative judgment virtually unreviewable."198

Not only does the judiciary not exercise its full judicial power and duty, it abdicates and transfers (or delegates) part of it. In cases challenging federal statutes as contrary to the Constitution, the remnant judicial power gets transferred to Congress. Described as "deferential"-and

193. See supra Section II.B.

194. See supra notes 12, 93-95 and accompanying text.

195. Gutierrez-Brizuela v. Lynch, 834 F.3d 1142, 1152 (10th Cir. 2016) (Gorsuch, J., concurring).

196. $I d$.

197. James M. McGoldrick, Jr., The Separation of Powers Doctrine: Straining Out Gnats, Swallowing Camels?, 18 PePr. L. Rev. 95, 99-100 (1990).

198. FCG v. Beach Commc'ns, Inc., 508 U.S. 307, 316 (1993); see also id. at 323 n.3 (Stevens, J., dissenting) (“[J] udicial review under the 'conceivable set of facts' test is tantamount to no review at all.”); McGoldrick, Jr., Retrospective, supra note 31, at 752-53 ("The rational basis test as applied by the Supreme Court is such a permissive level of review that it is effectively not judicial review at all."); Tara A. Smith, A Conceivable Constitution: How the Rational Basis Test Throws Darts and Misses the Mark, 59 S. Tex. L. Rev. 77, 98 (2017) ("Rational basis review exchanges the rule of law for the rule of 'close enough.'”). 
"enormously" so ${ }^{199}$ — the rational basis test requires courts to defer to Congress's interpretation of the Constitution even if they would find a better, fairer, or more correct reading. As Justice Gorsuch has observed, "every day, in courts throughout this country, judges manage with [their] traditional tools to reach conclusions about the meaning of statutes, rules of procedure, contracts, and the Constitution."200 Yet when evaluating a challenge that a statute violates the Constitution-no less a core part of the judicial power and duty than any of those other things a court does "every day"- the rational basis test requires courts to treat Congress's interpretation "as controlling even when it is 'not ... the best one." "201 Like Chevron deference, the rational basis test forces judges to "lay aside" the full scope of their judicial power and "declare affirmatively" that "the law is what [Congress] says it is," 202 often simultaneously "abandon[ing] what they believe is the best reading of" the Constitution. ${ }^{203}$ In short, with its substitution of a zone of deference for a judicial line of correctness, the rational basis test "wrests from Courts the ultimate interpretative authority to 'say what the law is,' and hands" over a large swath of that judicial power and duty to Congress. ${ }^{204}$

The abdication and transfer of judicial power endemic to the rational basis test rings dissonantly with Article III, which vests "every single drop" of the judicial power in the courts, not in Congress. ${ }^{205}$ With "[t]he interpretation of the laws" being "the proper and peculiar province of the courts," 206 the Constitution provides no basis for the exercise of any judicial power by Congress. To once again quote Justice Story, "in cases where [a court's] own judgment shall differ from that of other high functionaries," the court "is not at liberty to surrender, or to waive" the judicial power or its concomitant duty. ${ }^{207}$ Yet the rational basis test contravenes these principles and violates the separation of powers. Both the philo-

199. Chemerinsky, supra note 17 , at 401-02 ("The rational basis test is enormously deferential to the government and only rarely has the Supreme Court invalidated laws as failing rational basis review."); see also Farrell, Equal Protection, supra note 18, at 442 ("Equal protection's rational basis review-the requirement that a classification be rationally related to a permissible interest-is ordinarily a very deferential standard.").

200. Kisor v. Wilkie, 139 S. Ct. 2400, 2430 (2019) (Gorsuch, J., concurring).

201. Id. (alteration in original) (quoting Decker v. Nw. Envt'l Def. Ctr., 568 U.S. 597, 613 (2013)). (Then-Judge Gorsuch, of course, was writing about Chevron.)

202. Id. at 2440.

203. Michigan v. EPA, 135 S. Ct. 2699, 2712 (2015) (Thomas, J., concurring) (quoting Nat'l Cable \& Telecomm'ns Ass'n v. Brand X Internet Servs., 545 U.S. 967, $983(2005))$. (1803)).

204. Id. at 2712 (quoting Marbury v. Madison, 5 U.S. (1 Cranch) 137, 177

205. Ortiz v. United States, 138 S. Ct. 2165, 2190 (2018) (Alito, J., dissenting); see also supra note 160 and accompanying text.

206. The Federalist No. 78, supra note 61, at 467 (Alexander Hamilton).

207. United States v. Dickson, 40 U.S. (15 Pet.) 141, 162 (1841). 
sophical and historical background of the Constitution's separation of powers make that clear.

It is "striking" how much "intellectual background" supporting the separation-of-powers doctrine "speaks directly to the separation of lawmaking from law-exposition." 208 "Were [the judicial power] joined with the legislative [power]," Montesquieu warned, "the life and liberty of the [citizens] would be exposed to arbitrary control; for the judge would be then the legislator." 209 Writing much more recently, John Manning has explained that when legislative power is separate from both executive and judicial power, "legislators must fear that the executor will apply bad laws as written." 210 To that end, separation makes "it more difficult for lawmakers to write bad laws and then spare themselves from the effects of those laws through their control over the laws' application." 211 Montesquieu and Manning are but two examples in a long line of concurrent thought. ${ }^{212}$ By allowing Congress, the legislative branch of government, to also exercise judicial power, the rational basis test contests and defies this intellectual background.

What's more, the rational basis test upends the historical significance of tripartite structural separation, departing from a trajectory of liberalism and reverting to a more primitive state of affairs. In Ancient Rome, "[w] hen any doubt arose upon the construction of the Roman laws, the usage was to state the case to the emperor in writing, and take his opinion upon it."213 Decrying this ancient practice as "certainly a bad method of interpretation," Blackstone argued that "[t]o interrogate the legislature to decide particular disputes is not only endless, but affords great room for

208. Manning, Constitutional Structure, supra note 60, at 645-48.

209. Montesquieu, Spirit of the Laws bk. XI, ch. 6, 173 (Batoche Books ed., 2011) (1748).

210. Manning, Constitutional Structure, supra note 60, at 647.

211. Id. at 646; see also id. at 647 ("Under a regime of separation, if legislators wish to exempt themselves or their supporters from the effects of a law, the exemption must clearly appear in the legislation, where it will subject the legislators more readily to public accountability.").

212. See supra notes 56-79 and accompanying text; Manning, Constitutional Structure, supra note 60, at 647 ("[S] eparation of lawmaking from law-exposition also limits arbitrary government by providing legislators an incentive to enact rules that impose clear and definite limits upon governmental authority, rather than adopting vague and discretionary grants of power."); see also Robert H. Jackson, Problems of Statutory Interpretation, 8 F.R.D. 121, 123 (1948) ("[L] egislation is shaped by a majority ... [b]ut when a ruling majority has put its commands in statutory form . . the interpretation of their fair meaning and their application to individual cases should be made by judges as independent of politics as humanly possible ...."); Blackstone, supra note 97, at *259 ("Were [the judicial power] joined with the legislative, the life, liberty, and property, of the subject would be in the hands of arbitrary judges, whose decisions would be then regulated only by their own opinions, and not by any fundamental principles of law; which, though legislators may depart from, yet judges are bound to observe.").

213. Blackstone, supra note 97 , at $* 58$. 
partiality and oppression." ${ }^{214}$ Blackstone's sentiment had long echoed in English legal theory. For example, John Sadler wrote in 1649 that "if Lawmakers, be Judges, of Those that break their Laws; they seem to judg[e] in their Own Causes." 215 By the time "Charles II returned to govern England [in 1660], all exponents of limited government supported the doctrine of the separation of powers."216 England, however, did not enjoy a tripartite separation of powers; Parliament also served as the highest judicial court. While English law recognized the judicial duty and judicial review in general, the organization of English governmental bodies foreclosed judicial review of Parliamentary acts. ${ }^{217}$

Anxiety over excessive legislative power continued in the early days of independent America. ${ }^{218}$ One of the Framers' most immediate fears arose from their experience with colonial and early state legislatures. Noting a "powerful tendency" for legislatures to "absorb all power,"219 Madison feared that legislatures were "drawing all power into [their] impetuous vortex." ${ }^{220}$ At the Constitutional Convention, Gouverneur Morris "concurred in thinking the public liberty in greater danger from Legislative usurpations than from any other source."221 For example, colonial and early state legislatures before and during the Founding Era often functioned as courts of equity and decided the merits of controversies between parties, causing significant consternation about power accumulation and liberty deprivation. ${ }^{222}$

The Constitution's tripartite separation of powers responded to the perceived flaws of the English and early states' governments. In contrast to the English organization, and as a direct response to it, the Constitution's separation of judicial and legislative powers meant that even "the ordinary courts"- not to mention the Supreme Court- "could not defer to the decisions of any higher, legislative court."223 Moreover, reacting to excessive state legislative powers, and "[r] eacting to the perception that legislatively dominated state courts had rendered arbitrary judgments

214. Id.; see Decker v. Nw. Envt'l Def. Ctr., 568 U.S. 597, (2013) (Scalia, J., concurring in part and dissenting in part).

215. Gwrn, supra note 60, at 54 (quoting John Sadler, Rights of the KingDOM; OR Customs of Our Ancestors 87 (1649)).

216. Id. at 64 .

217. See supra notes 110-20 and accompanying text.

218. See supra note 64 and accompanying text.

219. 2 The Records of the Federal Convention of 1787, at 73-74 (Max Farrand ed. 1966) (July 21, 1787) (remarks of James Madison).

220. Patchak v. Zinke, 138 S. Ct. 897, 914 (2018) (Roberts, C.J., dissenting) (alteration in original) (quoting The Federalist No. 48, supra note 61, at 309 (James Madison)).

221. 2 The Records of the Federal Convention of 178776 (Max Farrand ed. 1966) (July 21, 1787) (remarks of Gouverneur Morris).

222. Patchak, 138 S. Ct. at 914-15 (Roberts, C.J., dissenting) (citing John F. Manning, Response, Deriving Rules of Statutory Interpretation from the Constitution, 101 Colum. L. Rev. 1648, 1662 (2001)).

223. Hamburger, Judicial Duty, supra note 108, at 22. 
rather than judgments according to law," the Constitution fully separated the judicial power and gave federal judges constitutional tenure and salary protections. ${ }^{224}$

With its near-complete abdication and transfer of the judicial power and duty to Congress, the rational basis test results in Congress being the reviewer of its own actions. Congress, instead of the courts, exercises a large portion of the judicial power to determine whether a statute is "made in Pursuance" of the Constitution. In short, Congress serves as a judge in its own case (not the judge, because the courts still exercise judicial power up to the zone of deference). This effectively regresses to the English model of incomplete separation, in which Parliament served both as the legislator and as the high court, dually possessing both legislative and judicial power. Although the rational basis test does not formally anoint Congress as the high court in the United States, it functionally does so-and in turn, it also functionally enfeebles judicial review of federal statutes. When one considers the full history of how the U.S. Constitution was a reaction to the English system, ${ }^{225}$ it is peculiar to see an effective return to that system-without any textual change to the relevant constitutional provisions. And just as peculiarly, the rational basis test returns Congress to a pre-Constitutional level of legislative power. The separation of powers was meant to constrain legislative excess; the rational basis test encourages it-or at least does nothing to stop it. It permits Congress to "draw[ ] all power into [its] impetuous vortex." 226

By disturbing the constitutional separation of powers, the rational basis test threatens the liberty-safeguarding purpose that separation advances. ${ }^{227}$ Whereas separation "diffuses power the better to secure liberty,"228 amalgamation centralizes power and threatens individual freedom. Moreover, "Article III protects liberty not only through its role in implementing the separation of powers, but also by specifying the defining characteristics of Article III judges," including, most prominently, their tenure and salary protection. ${ }^{229}$ Members of Congress, as well as others

224. Manning, Constitutional Structure, supra note 60, at 642. "As its text and our precedent confirm, Article III is an inseparable element of the constitutional system of checks and balances' that 'both defines the power and protects the independence of the Judicial Branch.' 'Stern v. Marshall, 564 U.S. 462, 482-83 (2011) (quoting N. Pipeline Constr. Co. v. Marathon Pipe Line Co., 458 U.S. 50, 58 (1982) (plurality op.)); see also Patchak, 138 S. Ct. at 915 (Roberts, C.J., dissenting); United States v. Klein, 80 U.S. (13 Wall.) 128, 146 (1872).

225. The Federalist No. 81, supra note 61, at 480-89 (Alexander Hamilton).

226. Patchak, 138 S. Ct. at 914 (Roberts, C.J., dissenting) (quoting The FederAList No. 48, supra note 61, at 309 (James Madison)).

227. See supra Section II.A.

228. Youngstown Sheet \& Tube Co. v. Sawyer, 343 U.S. 579, 635 (1952) (Jackson, J., concurring).

229. Stern, 564 U.S. at 483; see also Baldwin v. United States, 140 S. Ct. 690, 691-92 (2020) (mem.) (Thomas, J., dissenting from denial of certiorari); Perez v. Mortg. Bankers Ass'n, 575 U.S. 92, 120 (2015) (Thomas, J., concurring in the judgment); Hamburger, Law, supra note 104, at 507-08. 
exercising Article I power, by design have no such protections, meaning that when they exercise judicial power, they do so without Article III's safeguards. Even if the rational basis test's transfer of power and compromise of structural separation might not constitute "the very definition of tyranny," 230 it no doubt raises many of the general concerns that prompted the Constitution's tripartite division of powers in the first instance ${ }^{231}$-in the very same way that Chevron deference's transfer of power to the executive branch does.

In addition, just like how the executive branch's interpretations can constitutionally serve as evidence of statutory meaning, ${ }^{232}$ so too can Congress's interpretations serve as evidence of constitutional meaning. By arguing that the rational basis test is unconstitutional, I do not intend to imply that Congress can or should play no role in constitutional interpretation. Madison, for example, famously envisioned that liquidation of constitutional meaning would take place over time with input from all three branches. ${ }^{233}$ And because all legislators and officers take oaths to uphold the Constitution, it makes sense to presume that they intend to act constitutionally. When Congress enacts a statute, for instance, it does so with its own understanding that the statute is constitutional.

Under Madison's vision, though, other branches operate on their own interpretations of the Constitution only up until a particular case requires a judicial test of that branch's interpretation. Madisonian liquidation is not in tension with full exercise of judicial power by the courts. The question of whether lower-order law (a statute) is consistent with higher-order law (the Constitution) in a particular case calls for the exercise of judicial power and duty. And the rational basis test is deployed in particular cases, where only the judicial power is implicated. Like Chevron deference, the core problem with the rational basis test is not deference per se, but binding deference to a political branch's interpretation of higher-order law in a particular case. "Although Congress' expression of the view that it does have power ... is entitled to the most respectful consideration by the judiciary," Justice Harlan once wrote, "this cannot displace the duty of [the] Court to make an independent determination whether Congress has exceeded its powers." ${ }^{234}$

Besides the separation-of-powers violation outlined immediately above, the rational basis test raises two other related concerns. First, a court applying the rational basis test will uphold and apply a statute if "there is any reasonably conceivable state of facts that could provide a ra-

230. The Federalist No. 47, supra note 61, at 298 (James Madison).

231. See supra Section II.A.

232. See supra notes 171-74 and accompanying text.

233. See supra note 102.

234. Oregon v. Mitchell, 400 U.S. 112, 204 (1970) (Harlan, J., concurring in part and dissenting in part). 
tional basis for" the statute. ${ }^{235}$ In many circumstances, those "conceivable" "facts" are ginned up in litigation by executive-branch lawyers defending the constitutionality of the statute. ${ }^{236}$ When they accept an executive-branch official's "conceivable" "facts" in this manner to aid in their interpretation of law, courts do not merely accept one advocate's position over another's. They rather burke any independent search for truth, abdicate judicial power, and arguably violate the separation of powers.

Second, Clark Neily has argued that in applying the rational basis test, courts do not exercise judicial power in any way when applying the rational basis test. Rather, he argues, courts exercise some other peculiar power not contemplated by Article III:

The rational basis test at least arguably presents separation-ofpowers concerns as well, because it involves judges exercising a power that Article III of the Constitution does not bestow upon them. . . . Consistent with modern notions of what does (and does not) constitute a truly adjudicative proceeding, Blackstone defined the "judicial power" as the power "to examine the truth of the fact, to determine the law arriving upon that fact, and, if any injury appears to have been done, to ascertain and by its officers to apply the remedy." . . . [T] he defining essence of the modern rational basis test is its lack of concern for "the truth of the fact"- that is, the government's true ends in restricting the exercise of liberty or in distributing benefits and burdens unequally among individuals. As a result, a judge who applies that version of the rational basis test is no more exercising "the judicial power" than a judge who presides over a trial by combat or decides cases by tossing a coin. ${ }^{237}$

Finally, by abdicating a large portion of their judicial power and duty, courts applying the rational basis test also upend the Supremacy Clause's legal hierarchy. The Constitution indisputably ranks above federal statutes not "made in Pursuance" of the Constitution. Yet by permitting federal statutes to pass without the full scrutiny required by the judicial duty-regardless of whether a proper discharge of that duty would ulti-

235. FCC v. Beach Commc'ns, Inc., 508 U.S. 307, 313 (1993); see also supra note 28 and accompanying text.

236. See Neily, Litigation, supra note 7, at 546-47 (citing Powers v. Harris, 379 F.3d 1208, 1217 (10th Cir. 2004); then citing Burke Mountain Acad., Inc. v. United States, 715 F.2d 779, 783 (2d Cir. 1983)); see also Neily, No Such Thing, supra note 4, at 913 ("[T] he rational basis test permits-perhaps encourages-government lawyers and witnesses to misrepresent facts and distort reality; it destroys the principal of judicial neutrality by conscripting judges to act as advocates for the government; it turns a blind eye to corruption; it saddles plaintiffs with a logically impossible burden of proof; and it is often deliberately misapplied in order to achieve a preferred result.").

237. Neily, Litigation, supra note 7, at 552 (footnote omitted) (first quoting U.S. Const. art. III, $\$ \S 1-2$; then quoting 3 William Blackstone, Commentaries $* 25)$. 
mately uphold or strike down the statute-the courts dishonor the Supremacy Clause's text and objective. Analogously to when they apply Chevron deference, courts applying the rational basis test simultaneously diminish the elevated status of the Constitution and illegitimately lift the status of statutes not made in pursuance. How far each of those deviations goes may depend on the particular case; but if different levels of legal hierarchy end up in equipoise, the Constitution is violated. The rational basis test, in other words, disregards the Supremacy Clause's hierarchy by placing all procedurally proper statutes—not just LOTUS-MIP—on par with the Constitution. Although some scholars believe the contrary, the text of the Supremacy Clause reveals that "made in Pursuance" requires both procedural and substantive compliance. ${ }^{238}$ But the rational basis test effectively reduces "made in Pursuance" to a procedural-compliance requirement only.

The effect of the Supremacy Clause violation, for federal statutes, is not merely one of form. Bradford Clark has argued persuasively that the Supremacy Clause constrains federal power by requiring the political branches-and particularly Congress-to conform their acts to constitutional requirements. ${ }^{239}$ The Supremacy Clause, however, neither self-executes nor exists in a vacuum. It is part of a Constitution that creates a tripartite separation of powers with an independent judiciary vested with the whole judicial power. That judicial power comes with the duty to say what the law is-its best, fairest, and correct meaning-and to privilege higher-order law above lower-order law. "[J] udicial review under the Supremacy Clause reinforces the constitutional separations of powers" by "prevent[ing] Congress from authoritatively judging the scope of its own powers." ${ }^{240}$ Thus, courts can uphold the Constitution's protections-including the liberty-safeguarding structural separation of powers-only if they honor both the judicial power and Supremacy Clause. On the other hand, by "limit[ing] themselves to rational basis scrutiny of federal statutes," courts currently "surrender[ ] to Congress one of their essential functions under the Supremacy Clause." 241

The Supremacy Clause completes the analogy between the Chevron critique and my critique of the rational basis test. Both critiques locate a problem in courts—vested with the full judicial power-abdicating and transferring that power to a political branch. The meaning of the judicial power under Article III does not change depending on what type of legal text a court is applying or interpreting. Likewise, a court's duty to decide in accord with higher-law and to forego applying contrary lower-order law is the same in all cases, too. The Supremacy Clause's legal hierarchy makes clear that the following legal relationships all bear the same hierar-

238. See supra note 123 and accompanying text.

239. See generally Clark, supra note 123.

240. Id. at 112.

241. Id. at 124 . 
chical relationship: U.S. Constitution to federal statute not made in pursuance; U.S. Constitution to contrary state law; ${ }^{242}$ LOTUS-MIP to contrary administrative rule. The separation of powers, the meaning of judicial power, and the Supremacy Clause all work in tandem. Applied here, their principles render both Chevron deference and the rational basis test constitutionally problematic.

\section{Constitutional Problems with Rational Basis Review of State Statutes}

The central theme of my critique of rational basis review of federal statutes applies equally to rational basis review of state statutes: by erecting a zone of deference, courts abdicate a large part of their judicial power and duty, transferring that abdicated remnant to another governmental actor. Despite that core similarity, rational basis review of state statutes does not raise the same separation-of-powers problems raised by rational basis review of federal statutes. ${ }^{243}$ When used to review federal statutes, the rational basis test leads to transfer of remnant judicial power from courts to another federal branch (Congress). When used to review state statutes, by contrast, the rational basis test results in transfer of remnant judicial power from the federal courts to a state legislature. Although transferring judicial power from federal courts to the federal legislature might be analogous to transferring judicial power from federal courts to state legislatures (insofar as both Congress and state legislatures are both legislative bodies), that is all it is-an analogy. As traditionally understood, the U.S. Constitution's separation of powers does not govern relations between the federal government and state governments. When it comes to state statutes, then, no formal separation-of-powers doctrine actually condemns the rational basis test's transfer of federal judicial power.

Yet when dealing with state statutes, federal courts' abdication of judicial power and duty is still not without consequence. Just like with Chevron deference and with rational basis review of federal statutes, rational basis review of state statutes results in transfer of judicial power. By transferring federal judicial power to states, the rational basis test transfers federal sovereign power to a different sovereign-a state. ${ }^{244}$ In other words, the trans-

242. See supra Section II.C; infra Section IV.D.

243. This Article addresses only the rational basis test as used by federal courts. Just like federal courts, though, many state courts also use the rational basis test (or something very close to it) to review state and local government action under state constitutional provisions. And most state constitutions feature separation-of-powers principles similar to those found in the U.S. Constitution. Depending on state law, then, the separation-of-powers concerns raised above may also apply, by analogy, to state constitutional law. Put differently, it violates the federal constitutional separation of powers for a federal court to use the rational basis test to review federal governmental action; it may also violate a given state's constitutional separation of powers for a court of that state to use the rational basis test to review state or local governmental action.

244. This inter-sovereign transfer of power finds no justification in principles of federalism. See infra notes 266-71 and accompanying text. Moreover, no less than members of Congress, state actors lack the tenure, salary, and other indepen- 
fer is problematic not because it is inter-branch but because it is intersovereign. ${ }^{245}$

Although "under our federal system, the States possess sovereignty concurrent with that of the Federal Government," they do so "subject . . . to limitations imposed by the Supremacy Clause." 246 Whereas the Supremacy Clause's role in constraining federal power has been questioned (particularly with respect to the difference I draw between federal statutes not made in pursuance and LOTUS-MIP, a distinction necessary to support my argument), ${ }^{247}$ the Supremacy Clause's role in constraining state power (and elevating federal law above contrary state law) has always been accepted as blackletter. ${ }^{248}$ The Supremacy Clause requires state judges to obey federal supreme law "notwithstanding" state law "to the Contrary," thereby elevating supreme law-including the U.S. Constitution and LOTUS-MIP-above contrary state constitutions and statutes. In setting forth this hierarchy, the Supremacy Clause "upholds the written Constitution as the highest form of federal law"249 and offers further textual support for the discharge of judicial duty. By defying the Supremacy Clause, the rational basis test delinks judicial review of state statutes from constitutional text. And by permitting state statutes to pass without the full scrutiny required by the judicial duty-regardless of whether a proper exercise of that duty would ultimately uphold or strike down the statutecourts denigrate the Supremacy Clause's text and objective. Just like rational basis review of federal statutes, and analogously to Chevron deference, rational basis review of state statutes lowers the elevated status of the Constitution and improperly raises the status of state statutes.

dence protections conferred on federal courts and judges by Article III. See supra notes 227-31 and accompanying text; see also supra notes 166-70 and accompanying text.

245. As explained above, abdication and transfer of power from one federal branch to another not only violates the separation-of-powers, but also constitutes unauthorized subdelegation and divestment. See supra note 164. Those concerns ring just as true here, where a federal branch, vested with power initially belonging to the People, purports to unilaterally transfer that power to another actor (in this case, a state).

246. Tafflin v. Levitt, 493 U.S. 455, 458 (1990).

247. See supra note 123; see also, e.g., Jesse H. Choper, Judicial Review And the National Political Process: A Functional Reconsideration of the Role of the Supreme Court (1980); Clark, supra note 123, at 92-115; Jesse H. Choper, The Scope of National Power Vis-à-Vis the States: The Dispensability of Judicial Review, 86 YAle L.J. 1552 (1977); Kramer, supra note 123; Larry D. Kramer, Putting the Politics Back into the Political Safeguards of Federalism, 100 Colum. L. Rev. 215, 243 (2000).

248. For example, although no ambassador of scrutinizing judicial review, Herbert Weschler reasoned that the "prime function envisaged for judicial review-in relation to federalism-was the maintenance of national supremacy against nullification or usurpation by the individual states, the national government having no part in their composition or their councils." Herbert Wechsler, The Political Safeguards of Federalism: The Role of the States in the Composition and Selection of the National Government, 54 Colum. L. Rev. 543, 559 (1954).

249. Clark, supra note 123, at 113-14 (quoting U.S. Const. art. VI). 
This constitutional problem intensifies when one considers how most constitutional challenges to state statutes arise under the Fourteenth Amendment. The Fourteenth Amendment was enacted in the aftermath of the Civil War to stymie state governments from violating the civil liberties of freed slaves and white Republicans, to ensure the constitutionality of the Civil Rights Act of 1866, and to combat the notorious and discriminatory "Black Codes." 250 Whatever the original Constitution established as the framework for inter-sovereign relations, the Fourteenth Amendment completely refigured it, elevating the status of federal rights and restricting state power in the face of those rights. Unlike before its ratification, the Fourteenth Amendment gave the federal government direct authority to limit excessive and distorted state power; the Amendment was designed to be, and textually is, a limitation on state power. Coupled with the Supremacy Clause, the Fourteenth Amendment rejects the rational basis test's systematically deferential stance toward state power. Especially in challenges against state statutes under the Fourteenth Amendment, rational basis review hardly seems consistent with either that Amendment or the Supremacy Clause, both of which patently establish the primacy of federal law-and particularly the federal Constitution.

\section{Counterarguments}

In this Part, I anticipate and respond to the most obvious counterarguments to my argument.

First, one could argue that the Chevron analogy is inapposite. Chevron deference involves abdication of judicial power and transfer of that power to the executive branch, specifically to administrative agencies. Part of the reason that the transfer under Chevron is problematic, the argument goes, is that the judicial power ends up in the hands of unelected agency heads and bureaucrats. The deference, in other words, is to unaccountable officers. By contrast, the rational basis test, despite its abdication and transfer of judicial power, transfers that power to Congress or state legislatures. The remnant power ends up in the hands of elected federal or state legislators. The deference is to officers directly accountable to the people.

Although observant, this argument does not actually address the core separation-of-powers and Supremacy Clause concerns I raise. A critical premise of my argument is that Article III's Vesting Clause vests the federal judicial power in the federal courts-not elsewhere. The constitutional violation arises upon transfer of power, whether that transfer be to the executive branch, Congress, or state legislatures.

Moreover, this argument ignores history to justify transfer of judicial power under the rational basis test on the grounds that Congress is elected. It was their early experience with elected state legislatures that

250. See, e.g., Laurence H. Tribe, American Constitutional Law 1320-31 (3d ed. 2000); Michael Kent Curtis, No State Shall Abridge 26-56 (1986); Philip Hamburger, Privileges or Immunities, 105 Nw. U. L. Rev. 61, 116-17 (2011). 
caused the Framers to fear majoritarian tyranny and the "impetuous vortex" of legislative power ${ }^{251}$ - and prompted them to respond by implementing a tripartite separation of powers and by giving federal judges independence, tenure, and salary protection.

Second, one may question the Chevron analogy on other grounds. Courts using Cheuron deference, this argument proceeds, examine the text of two sources of law: a LOTUS-MIP and a federal administrative rule. When the former is ambiguous, courts defer to the executive branch. Cheuron is thus an interstitial test triggered in such challenges, and it exists independently of the text of the higher-order LOTUS-MIP. By contrast, the rational basis test is not an independent, interstitial test but rather an interpretation or construction of a particular constitutional provision (say, the Due Process Clause). Under this argument, the rational basis test $d e$ pends on and simply implements the text of the Due Process Clause. This argument fails.

Just like Chevron deference, the rational basis test does not purport to interpret the text of any substantive higher-order law. Chevron itself has nothing to do with the text of the Clean Air Act, for example; it is a tool courts use when interpreting various federal statutes, including the Clean Air Act. The rational basis test likewise bears no relation to the text of the Due Process Clause (or any constitutional provision); it is rather an independent, interstitial tool courts use when interpreting higher-order constitutional provisions.

We know this, in part, because courts do not limit their use of the rational basis test to the Due Process Clause (or any single constitutional provision). Courts use it when parties challenge lower-order statutes under any number of constitutional provisions, including the Commerce Clause, the Takings Clause, the Due Process Clause, and the Equal Protection Clause. ${ }^{252}$ Because those various constitutional provisions differ in text and substance, one cannot seriously maintain that the rational basis test is a textual interpretation-much less the best, fairest, and correct interpretation-of any one of them. That courts rely on the rational basis test when analyzing so many different constitutional challenges indicates that, just like Cheuron, it exists independently of the text of any higherorder law.

We also know that the rational basis test is an independent, interstitial tool because even with respect to a single constitutional provision (say, again, the Due Process Clause), courts do not always look to the rational basis test. Sometimes courts employ a different test, such as strict scrutiny.

251. The Federalist No. 48, supra note 61, at 309 (James Madison); see also Patchak v. Zinke, 138 S. Ct. 897, 914-15 (2018) (Roberts, C.J., dissenting); Stern v. Marshall, 564 U.S. 462, 482-84 (2011); United States v. Klein, 80 U.S. (13 Wall.) 128, 146 (1872); 3 John Adams, A Defence of the Constitutions of Government of the United States of America 290-91 (1788); supra note 64 and accompanying text.

252. See supra notes $44-55$ and accompanying text. 
If the rational basis test were simply what the text of a particular constitutional provision required, then courts would use it uniformly.

To be sure, the specific analysis a court writes down in a Chevron case might look slightly different from the analysis in a rational basis case. But that is due to the sheer number of federal statutes compared to constitutional provisions. When entertaining a statutory challenge to a federal administrative rule, courts usually begin with a fairly thorough analysis of the higher-order LOTUS-MIP before implementing Chevron deference; they do so to determine whether Chevron deference is appropriate and because there is often little binding precedent about the specific statutory provision at issue. When entertaining a constitutional challenge to a statute, however, federal courts often can simply cite precedent that has already taken the analysis of the higher-order constitutional provision to the point of determining that the rational basis test is appropriate. In other words, Chevron courts must first analyze the statute up to the zone of deference, because no binding case has done so before. But many courts have already interpreted constitutional provisions up to the zone of deference, so courts need not "show their work" in as great of detail. (This is not invariably the case, of course, as courts often spill much ink deciding whether the rational basis test or some more scrutinous test is appropriate.)

So, in both Chevron and rational basis cases, courts begin with a substantive higher-order law (LOTUS-MIP in Chevron; constitutional provision for rational basis review); employ a deferential interstitial test that exists independently of the text and substance of that higher-order law (Chevron; rational basis test); and then spit out conclusions about the challenged lower-order provision based on that deference (federal regulation; federal or state statute). If anything, courts employing the rational basis test (as compared to courts employing Chevron deference) further distance themselves from the actual text and substance of the higher-order law at issue, which in turn leads to an even greater abdication and transfer of judicial power and duty.

Third, one might criticize my argument as extending beyond the rational basis test and applying to nearly all judicial review (i.e., review not using the rational basis test). I must share, first off, that I intend for my argument to apply only to rational basis review of federal and state statutes. I do not intend to opine on the constitutionality of the strict-scrutiny test, the intermediate-scrutiny test, or any other test any court has developed to review the constitutionality of a government act. Any such investigation is beyond the scope of this Article. That said, the background principles of constitutional law discussed in this Article-separation of powers, the meaning of judicial power, the judicial duty, and the Supremacy Clause's legal hierarchy-are broadly applicable. They undoubtedly extend beyond my argument. What I have said about those background principles may form an appropriate starting point for evaluating other constitutional questions. 
Fourth, one might attempt to justify the rational basis test by citing the traditional standard for declaring lower-order law void or unenforceable in a particular case. As explained, the judicial power and duty requires courts to acknowledge legal hierarchy and to privilege higher-order law over contrary lower-order law. ${ }^{253}$ Traditionally, higher-order law was held to displace lower-order law only when a "clear" or "irreconcilable" conflict existed between the two sources. ${ }^{254}$ In historic English practice, for example, "the higher law displaced the lesser obligation only if the contradiction were manifest." 255 "That standard continued to be the one embraced by the exercise of judicial power" during the Founding Era and long after. ${ }^{256}$ Under the reasonable basis test used in the late 1800 s and early $1900 \mathrm{~s},{ }^{257}$ the "reviewing court was not to declare . . the legislative enactment unconstitutional except in a 'clear case." "258

Whatever its merits or its constitutionality when viewed in isolation, this standard of clarity does not justify the rational basis test. Unlike the rational basis test, requiring "clear" or "irreconcilable" conflict still envisions that courts exercise the full judicial power. Courts still need to ascertain the best, fairest, and correct interpretation of both the higher-order law and the lower-order law and then compare those sources. This is different in kind from the rational basis test, under which courts abdicate and transfer part of the judicial power to a different actor to interpret the higher-order law.

Fifth, one might contend that my argument supports judicial supremacy ${ }^{259}$ run amok. To be sure, my argument assumes that courts

253. See supra Section II.B.

254. The Federalist No. 78, supra note 61, at 466 (Alexander Hamilton). That is, the judicial power and duty supports holding a state or federal statute void or unenforceable only if it is at "irreconcilable variance" with the Constitution. Id.

255. John O. McGinnis, Reforming Constitutional Review of State Economic Legislation, 14 Geo. J.L. \& Pub. Pol'y 517, 522-23 (2016) [hereinafter McGinnis, Reforming] (citing Hamburger, LAw, supra note 104, at 309).

256. $I d$.

Cases involving state judicial review before the Federal Constitution, comments in the debates over the Federal Constitution, federal judicial decisions in the pre-Marshall Court era, federal judicial decisions in the Marshall Court era, and state judicial decisions involving state constitutions after the framing of the Federal Constitution all followed a similar standard.

Id. (citing John O. McGinnis, The Duty of Clarity, 84 Geo. Wash. L. Rev. 843, 876-95 (2016)).

257. See supra notes $31-37$ and accompanying text.

258. Jackson, Classical, supra note 8, at 497 (quoting The Sinking Fund Cases, 99 U.S. 700,718 (1878)). I do not intend to suggest that returning to the reasonable basis test either would or would not be constitutional.

259. Although the term "judicial supremacy" may be susceptible to any number of definitions, a fairly standard one comes from Erwin Chemerinsky- "that the Supreme Court should be viewed as the authoritative interpreter of the Constitution and that we should deem its decisions as binding on the other branches and levels of government, until and unless constitutional amendment or subsequent decision overrules them." Erwin Chemerinsky, In Defense of Judicial Supremacy, 58 
have authority to conclusively determine constitutional meaning in particular cases. But that position merely restates the judicial power and duty; it does not reflect expansive judicial supremacy. Indeed, it is generally recognized that federal courts are the final arbiter of the Constitution's meaning, at least within the confines of particular cases. ${ }^{260}$ Drawing on the Supremacy Clause and the judicial power, the Supreme Court has declared "that the federal judiciary is supreme in the exposition of the law of the Constitution." 261 This "basic principle" "has ever since been respected by this Court and the Country as a permanent and indispensable feature of our constitutional system." ${ }^{262}$ Moreover, just because a court in a particular case determines that a statute is contrary to the Constitution does not mean the court is legislating generally applicable rules of conduct. At most, the court is negating, and "judicial negation is not legislation"263:

If Congress refuses to enact a statute, perhaps because in its opinion it would be unconstitutional, it does not matter if a court would uphold it as constitutional. Courts cannot mandate the passage of a statute. On the issue of which statutes to enact the legislative power the legislature is "supreme." Only if the Congress enacts a measure because enough of its members believe it to be constitutional (or do not care) and the president signs the bill believing it is constitutional (or does not care) may the Court have the opportunity to express its opinion on its constitutionality. A court's power to negate unconstitutional legislation renders it equal, not superior, to the other branches. ${ }^{264}$

Put differently, Congress, the executive branch, and the states certainly may interpret the Constitution when exercising their respective powers. But a federal court's interpretation is authoritative when that interpretation emerges from an exercise of judicial power. ${ }^{265}$

WM. \& Mary L. Rev. 1459, 1450 (2017). For purposes of this Article, I neither endorse nor object to this definition or to the principle it embodies. Rather, in this paragraph of text, I simply clarify that accepting my argument about the rational basis test does not require one to also endorse an expansive notion of judicial supremacy.

260. See supra note 102 and accompanying text.

261. Cooper v. Aaron, 358 U.S. 1, 18 (1958); see supra note 102 and accompanying text.

262. Cooper, 358 U.S. at 18.

263. Barnett, Judicial Power, supra note 119, at 133; see also supra note 186.

264. Barnett, Judicial Power, supra note 119, at 133. Indeed, "the original meaning of the 'judicial power' in Article III, included the power of judicial nullification." Id. at 117; see also Prakash \& Yoo, supra note 119.

265. See Robert A. Schapiro, Judicial Deference and Interpretive Coordinacy in State and Federal Constitutional Law, 85 Cornell L. Rev. 656, 661-62 (2000) (Although "[o]ther branches of government and the citizenry at large may have opinions about constitutional meaning," the Supreme Court "has a privileged role in constitutional interpretation."); see also Scott E. Gant, Judicial Supremacy and Nonjudicial Interpretation of the Constitution, 24 Hastings Const. L.Q. 359, 367-68 (1997). 
Sixth, one might argue that the rational basis test is supported or even required by the separation of powers or by federalism. Supreme Court justices as ideologically diverse as Justices Stephen Breyer and Samuel Alito have suggested as much. ${ }^{266}$ Along similar lines, the Beach Court positively described the rational basis test as "a paradigm of judicial restraint."267 As mentioned, similar arguments have been advanced in support of Chewron. ${ }^{268}$ When higher-order law contains ambiguity, the argument goes, resolving that ambiguity requires a political branch to make policy judgments. ${ }^{269}$ Although this entire Article exposes the weaknesses of this counterargument, a few additional words are warranted.

This counterargument fails to distinguish between deference to policy judgment and deference to interpretation of law. Abdication and transfer of judicial power and duty-i.e., deference to other-branch interpretation of law, or saying what the law is, in a particular case-differs from deference to policy judgment. Determining whether a lower-order law (statute)

266. See United States v. Windsor, 570 U.S. 744, 813 (2013) (Alito, J., dissenting) (" $[\mathrm{I}] \mathrm{n}$ rational basis cases ... . the courts have been very reluctant, as they should be in our federal system and with our respect for the separation of powers, to closely scrutinize legislative choices as to whether, how, and to what extent those interests should be pursued." (quoting City of Cleburne v. Cleburne Living Ctr., Inc., 473 U.S. 432, 441-42 (1985))); Bd. of Trs. of Univ. of Ala. v. Garrett, 531 U.S. 356, 383-84 (2001) (Breyer, J., dissenting) (quoting same passage from Cleburne). As one scholar has lamented, the rational basis test "affirmatively shuns reasoned analysis in the name of federalism and separation of powers." Susannah W. Pollvogt, Beyond Suspect Classifications, 16 U. PA. J. Const. L. 739, 743 (2014).

267. FCC v. Beach Commc'ns, Inc., 508 U.S. 307, 314 (1993). For an interesting discussion about "judicial restraint" and how different political contingencies have wavered from embracing it to rejecting it, see Jack M. Balkin, Why Liberals and Conservatives Flipped on Judicial Restraint: Judicial Review in the Cycles of Constitutional Time, 98 Tex. L. Rev. 215 (2019). See generally Damon Root, Overruled: The Long War for Control of the U.S. Supreme Court (2014); Joseph S. Diedrich, Article III, Judicial Restraint, and This Supreme Court, 72 S.M.U. L. REv. 235 (2019).

268. See supra notes 175-79 and accompanying text.

269. See id. This argument is often phrased in terms of institutional competence: "Sometimes it is argued that the Court should defer to legislatures on economic issues because they have a superior capacity to determine social facts, like the effects of legislation on health and safety." McGinnis, Reforming, supra note 255, at 522 (citing Garrett, 531 U.S. at 384 (Breyer, J., dissenting) ("Unlike courts, Congress can readily gather facts from across the Nation, assess the magnitude of the problem, and more easily find an appropriate remedy." (internal quotation marks omitted)). Asserting that "this claim is wrong," John McGinnis has argued:

As an elected body, Congress is designed to respond to its constituents' subjective desires, not to the objective facts of the world, and it is subject to interest group pressure. In contrast, the judiciary is relatively insulated from the preferences of constituents and less subject to partisan bias and interest group pressure. Its salient institutional structure is the adversarial proceeding where each side has incentives to scrutinize relentlessly the factual claims of its opponent. Accordingly, the judiciary would appear to be at least as good, if not a superior, fact-finder, both because of its institutional capacity and because of its relative lack of bias.

Id. (footnotes omitted); see also John O. McGinnis \& Charles W. Mulaney, Judging Facts Like Law: The Courts v. Congress in Social Fact-Finding, 25 Const. Comment. 69, 94-110 (2008). 
is consistent with or contrary to a higher-order law (Constitution) is a question of law to be answered by exercising the judicial power and duty. It is not a question of policy, and courts should not abdicate their duty in the name of avoiding making policy judgments. On the other hand, determining what actions to take within the constitutional scope of authority is a matter of policy for the political branches, not a question of law to be scrutinized and answered by courts exercising judicial power. Put differently, once Congress or a state legislature has made a policy judgment and enacted a statute, it remains an exercise of judicial power, within the context of a particular dispute, to determine whether that statute is consistent with or contrary to higher law. ${ }^{270}$ Although a court may not substitute a different policy judgment, it still has the power and duty to say whether the statute conflicts with the Constitution. The Constitution dictates what Congress and the states may do-not the other way around; Congress and the states don't get to say what the Constitution means in particular cases. ${ }^{271}$ Neither the separation of powers nor federalism contemplates abdication or transfer of judicial power in the name of deference or restraint.

Seventh and finally, one might argue that I advocate for a return to the Lochner era. Not so. To begin, my argument establishes only that the existing rational basis test violates the Constitution; it does not prescribe what should take its place. True enough, the modern rational basis test emerged as a reaction against the perceived missteps of the Supreme Court in Lochner and contemporaneous cases. ${ }^{272}$ Yet just because the modern rational basis test is unconstitutional does not imply that Lochnerera jurisprudence was constitutionally sound. Further, my argument relates only to the judicial test for evaluating constitutionality-not to outcomes.

Relatedly, some might contend that if the rational basis test is indeed unconstitutional, then whatever test replaces it would scrutinize legislation more strictly. And because most statutes reviewed under the rational basis test concern economic matters, a stricter test would elevate the status of economic rights. ${ }^{273}$ Although some might object to this elevation on policy grounds, it remains true that no non-economic rights would be denigrated or demoted. Rights need not be a zero-sum game. Federal courts

270. See Barnett, Judicial Power, supra note 119, at 133.

271. Relatedly, one might argue that the rational basis test reduces conflict between branches "by reducing the number of cases in which the judiciary provides an honest assessment of the other branches' handiwork." Neily, Litigation, supra note 7, at 556. Even if inter-branch conflict might be undesirable in some ways, the separation of powers envisions that each branch will monitor the others to preserve limits on power and to foster individual liberty. The branches, in fact, are often described as "co-equal." If courts set out to reduce inter-branch conflict, however, they are likely to reduce their own power while simultaneously aggrandizing the power of Congress-thus disturbing co-equality.

272. See supra notes $36-41$ and accompanying text.

273. See, e.g., Sherry, supra note 17 , at 564. 
can protect certain rights more strongly without compromising other rights.

\section{Conclusion}

Departing from English and early state practice, the U.S. Constitution establishes a tripartite separation of powers and an independent judiciary. Article III vests federal courts—and no other branch-with the "judicial power." This power entails applying law to decide particular disputes; interpreting the law in order to apply it; and, in the face of multiple conflicting sources of law, applying higher-order law and rendering lower-order law void or unenforceable (at least in the particular case at hand). On that last point, the Supremacy Clause instructs that the U.S. Constitution prevails over federal statutes not "made in Pursuance" of the Constitution and over contrary state statutes.

When a party argues that a lower-order statute contravenes the Constitution, courts often apply the rational basis test, which sanctions any statute that rationally relates to a legitimate government interest. In applying this test, however, courts abdicate part of their judicial power and duty. Instead of exercising judicial power to ascertain the best, fairest, and correct interpretation of the constitutional provision at issue, they merely set a zone of deference, within which all rational interpretations reside. The abdicated judicial power is effectively transferred to Congress or the state legislature (as the case may be), which exercises the remnant judicial power. Instead of interpreting the Constitution to say what it means, courts say only what it could mean, deferring to a legislature to fully ascertain meaning. When used to review a federal statute, this arrangement violates the separation of powers. And when used to review any statute, it subverts the Supremacy Clause's established legal hierarchy, elevating the status of lower-level statutes and, accordingly, devaluing the Constitution.

Chevron deference and the well-known separation-of-powers argument against it provide an apt analogy that bolsters my claims. When a party challenges an administrative rule (lower-order law) as contrary to an ambiguous higher-order law (LOTUS-MIP), the legal hierarchy is once again implicated. Yet just like with the rational basis test, courts applying Chevron deference fail to fully exercise the judicial power or discharge the judicial duty. Instead, they merely set a zone of deference, upholding and applying the lower-order administrative rule so long as it permissibly or reasonably construes the higher-order statute. Just like with the rational basis test, this framework undermines the separation of powers and the Supremacy Clause. But unlike with the rational basis test, the separationof-powers problems with Chevron deference have been well-documented. I assert, however, that anyone who accepts such arguments against Cheuron must, by extension, accept that the rational basis test fails for the same reason. 
Diedrich: Separation, Supremacy, and the Unconstitutional Rational Basis Te

2021]

Article III provides that courts have the "judicial power" to decide particular cases, and as Chief Justice Marshall famously proclaimed in Marbury, that power and "duty" entails "say[ing] what the law is." 274 Cheuron deference and the rational basis test both distort these constitutional imperatives. Yet despite Chevron's misstep, one cannot deny that in the context of deciding particular cases, it is the "province and duty of the Judicial Department" - not the executive branch-to "say what the law is" - not what the law permissibly or reasonably might be, or what the executive branch says it is. And despite the rational basis test, it is still the "province and duty of the Judicial Department"-not Congress, not state legislatures-to "say what the [Constitution] is" - not what the Constitution rationally could be, or what Congress or a state legislature says it is.

In sum, the rational basis test is unconstitutional. Others before me have reached that same conclusion. ${ }^{275}$ In this Article, I have presented a new theory explaining why: the test violates the structural separation of powers and the Supremacy Clause.

274. Marbury v. Madison, 5 U.S. (1 Cranch) 137, 177 (1803).

275. See supra notes 3-9 and accompanying text. 